\title{
Ten-Item Internet Gaming Disorder Test (IGDT-10): Measurement invariance and cross-cultural validation across seven language-based samples
}

Running head: IGDT-10 cross-cultural validation

Orsolya Király ${ }^{1}$, Beáta Bőthe ${ }^{1,2}$, Jano Ramos-Diaz ${ }^{3}$, Afarin Rahimi-Movaghar ${ }^{4}$, Katerina Lukavska $^{5}$, Ondřej Hrabec ${ }^{5}$, Michal Miovsky ${ }^{5}$, Joël Billieux ${ }^{6}$, Jory Deleuze ${ }^{7}$, Filip Nuyens ${ }^{7,8}$, Laurent Karila $^{9}$, Mark D. Griffiths ${ }^{8}$, Katalin Nagygyörgy ${ }^{1}$, Róbert Urbán ${ }^{1}$, Marc N. Potenza ${ }^{10}$, Daniel King ${ }^{11}$, Hans-Jürgen Rumpf ${ }^{12}$, Natacha Carragher ${ }^{13}$, and Zsolt Demetrovics ${ }^{1}$

${ }^{1}$ Institute of Psychology, ELTE Eötvös Loránd University, Budapest, Hungary

${ }^{2}$ Doctoral School of Psychology, ELTE Eötvös Loránd University, Budapest, Hungary

${ }^{3}$ Centre for Interdisciplinary Science and Society Studies (CIICS), Universidad de Ciencias y Humanidades, Lima, Peru

${ }^{4}$ Iranian National Center for Addiction Studies (INCAS), Tehran University of Medical Sciences, Tehran, Iran

${ }^{5}$ Charles University, Prague, Czech Republic

${ }^{6}$ Addictive and Compulsive Behaviours Lab, Institute for Health and Behaviour, University of Luxembourg, Esch-sur-Alzette, Luxembourg

${ }^{7}$ Laboratory for Experimental Psychopathology (LEP), Psychological Science Research Institute, Université Catholique de Louvain, Louvain-la-Neuve, Belgium

${ }^{8}$ International Gaming Research Unit, Psychology Department, Nottingham Trent University, Nottingham, United Kingdom

${ }^{9}$ Addiction Research and Treatment Center, Paul Brousse Hospital, Paris Sud-11 University, AP-HP, INSERM U1000, Villejuif, France

${ }^{10}$ Yale School of Medicine and Connecticut Mental Health Center, New Haven, CT, USA

${ }^{11}$ School of Psychology, The University of Adelaide, Australia

${ }^{12}$ University of Lübeck, Department of Psychiatry and Psychotherapy, Lübeck, Germany

${ }^{13}$ World Health Organization Headquarters, Geneva, Switzerland

\section{Final, accepted manuscript}

(C) 2018, American Psychological Association. This paper is not the copy of record and may not exactly replicate the final, authoritative version of the article. Please do not copy or cite without authors permission.

Corresponding author: Orsolya Király, Institute of Psychology, ELTE Eötvös Loránd University; 1063 Budapest, Izabella u. 46, Hungary, Tel: +36 30514 7414; Fax: +36 1461 2697; Email: orsolya.papay@gmail.com; kiraly.orsolya@ppk.elte.hu.

Acknowledgements: This study was supported by the Hungarian National Research, Development and Innovation Office (grant number: K111938, KKP126835) and the COST 
Action (grant number: CA16207) funded by the Horizon 2020 Framework Programme of the European Union. This work was completed in the ELTE Institutional Excellence Program (7833/2018/FEKUTSRAT) supported by the Hungarian Ministry of Human Capacities. Orsolya Király was supported by the ÚNKP-17-4 New National Excellence Program of the Ministry of Human Capacities. Marc Potenza was supported by a Center of Excellence grant from the National Center for Responsible Gaming. Katerina Lukavska, Ondřej Hrabec and Michal Miovsky were supported by the Institutional Support Programme of Charles University (PROGRES-Q06). The funding institutions had no role in the study design or the data collection, analysis and interpretation of the data, writing the manuscript, or the decision to submit the paper for publication. Furthermore, we would like to specially thank Rabert Farnam, Hossein Rafiemanesh, and Marzieh Hamzezadeh for their help provided in the Persian data collection. We would also like to specially thank Claudia Guevara-Cordero and students from the UIGV for their support in the Peruvian data collection.

Conflict of Interest: The authors declare that they have no conflict of interest with respect to the content of this manuscript. The authors have the following disclosures. Marc N. Potenza has: consulted for and advised Shire, INSYS, Rivermend Health, Opiant/LightlakeTherapeutics and Jazz Pharmaceuticals; received (to Yale) unrestricted research support from the Mohegan Sun Casino and grant support the National Center for Responsible Gaming; participated in surveys, mailings, or telephone consultations related to drug addiction, impulse control disorders or other health topics; consulted for and/or advised legal and gambling entities on issues related to addictive behaviors; provides clinical care in the Connecticut Department of Mental Health and Addiction Services Problem Gambling Services Program; performed grant reviews for the National Institutes of Health and other agencies; has edited journals and guestedited journal sections; given academic lectures in grand rounds, CME events and other clinical/scientific venues; and generated books or chapters for publishers of mental health texts. The views presented in this manuscript represent those of the authors and not necessarily those of the funding agencies who had no input into the content of the manuscript. Laurent Karila receives consulting fees from Sanofi Aventis, Gillead, Eutherapie, Bouchara-Recordati, JansseCilag, Takeda, DA Pharmaceuticals.

This paper has not been, nor will be, published in whole or in part by any other journal and is under consideration for publication elsewhere. However, parts of the results have been previously presented on the $4^{\text {th }}$ International Conference on Behavioral Addictions, in Haifa, Israel between 20-22 February, 2017. 


\title{
Ten-Item Internet Gaming Disorder Test (IGDT-10): Measurement invariance and cross-cultural validation across seven language-based samples
}

\begin{abstract}
Background and aims: The Ten-Item Internet Gaming Disorder Test (IGDT-10) is a short screening instrument developed to assess Internet gaming disorder (IGD) as proposed in the DSM-5, adopting a concise, clear, and consistent item-wording. According to initial studies conducted in 2014, the instrument showed promising psychometric characteristics. The present study tested the psychometric properties, including language and gender invariance, in a large international sample of online gamers. Methods: Data were collected from 7,193 participants comprising Hungarian ( $\mathrm{n}=3,924)$, Iranian $(\mathrm{n}=791)$, English-speaking $(\mathrm{n}=754)$, French-speaking $(n=421)$, Norwegian $(n=195)$, Czech $(n=496)$, and Peruvian $(n=612)$ online gamers via gamingrelated websites and gaming-related social-networking-site groups. Results: A unidimensional factor structure provided a good fit to the data in all language-based samples. In addition, results indicated both language and gender invariance on the level of scalar invariance. Criterion and construct validity of the IGDT-10 was supported by its strong association with the Problematic Online Gaming Questionnaire and moderate association with weekly gaming time, psychopathological symptoms, and impulsivity. The proportions of each sample that met the cut-off score on the IGDT-10 varied between $1.61 \%$ and $4.48 \%$ in the individual samples, except for the Peruvian sample (13.44\%). Conclusions: The IGDT-10 shows robust psychometric properties and appears suitable for conducting cross-cultural and gender comparisons across seven languages.
\end{abstract}

Keywords: Internet gaming disorder, gaming addiction, measurement invariance, crosscultural comparison, problematic gaming 
Video gaming is one of the most popular entertainment activities, especially among children and young adults (van den Eijnden, Lemmens, \& Valkenburg, 2016). In part due to its rewarding nature, some gamers play excessively and a minority appear to show addiction-like symptoms (Király, Nagygyörgy, Griffiths, \& Demetrovics, 2014). Research into the area of problematic and addictive gaming dates back to the 1980s and has intensified more recently. Problematic video gaming, operationalized as 'Internet gaming disorder' (IGD), was included in Section 3 ('Emerging Measures and Models') of the latest (fifth) edition of the Diagnostic and Statistical Manual of Mental Disorders (DSM-5), as a condition warranting further study (American Psychiatric Association, 2013). Furthermore, the upcoming $11^{\text {th }}$ Revision of the International Classification of Diseases (ICD-11) also proposes to recognize 'Gaming disorder' (GD), and is similar to the DSM-5's classification of IGD (World Health Organization, 2018).

The establishment of a formal gaming-related diagnosis has been much debated among scholars with respect to the validity of a diagnostic entity (e.g., Aarseth et al., 2017; Griffiths et al., 2016; Király, Griffiths, \& Demetrovics, 2015; Kuss, Griffiths, \& Pontes, 2017). Some of the main arguments against the formalization of the disorder is the lack of consensus regarding the term used, its operational definition (i.e., criteria), its assessment, the course of the disorder, and the precise features of the problematic behavior (Aarseth et al., 2017). Thus, as researchers who support the inclusion of GD in ICD-11 at this stage state, there is a need for data that may help promote reaching further consensus to aid in advancing IGD/GD-related prevention, treatment and research efforts (Griffiths, Kuss, Lopez-Fernandez, \& Pontes, 2017; Higuchi et al., 2017; Király \& Demetrovics, 2017; Lee, Choo, \& Lee, 2017; Müller \& Wölfling, 2017). Furthermore, the current state of research regarding the clinical relevance of gaming, its health burden and the neurobiological similarities to other addictive disorders warrants inclusion of this condition in ICD-11 as a behavioral addiction (Saunders et al., 2017).

A common issue in the field of IGD has been the lack of consistency in screening tools. This was highlighted in a systematic literature review conducted before the publication of the DSM-5 by King et al. (2013) which identified 18 different measurement instruments assessing problematic gaming. As the authors reported, the instruments varied considerably in content, which is unsurprising given the lack of any consensual diagnostic criteria prior to the inclusion of IGD in Section 3 of the DSM-5, and many of these instruments had not been tested psychometrically. Since the publication of the DSM-5, a number of other tools have been developed to assess IGD (van Rooij, Van Looy, \& Billieux, 2017). For instance, instruments include the 27-item Internet Gaming Disorder Scale and its short, nine-item version (IGDS; Lemmens, Valkenburg, \& Gentile, 2015) or the nine-item Internet Gaming Disorder Scale Short-Form (IGDS-SF9; Pontes \& Griffiths, 2015) which were both based on the nine DSM-5 criteria. The latter has been examined in a number of languages such as Italian (Monacis, Palo, Griffiths, \& Sinatra, 2016), Turkish (Evren et al., 2018), Portuguese (Pontes \& Griffiths, 2016), or Slovenian (Pontes, Macur, \& Griffiths, 2016), and has also undergone measurement invariance testing in cross-cultural studies comparing, for instance, data from the UK, US and India (Pontes, Stavropoulos, \& Griffiths, 2017). While instruments such as these appear more consistent because they all try to operationalize the same criteria, examining their psychometric properties in a comprehensive way is important for reliable and valid research in the area.

The Ten-Item Internet Gaming Disorder Test (IGDT-10; Király, Sleczka, et al., 2017) is a short screening instrument that assesses IGD as operationalized in the DSM-5, adopting a 
concise, clear, and consistent item-wording that adequately reflects the IGD construct. It was developed using a large sample of online gamers and showed promising psychometric properties based on initial analyses. Results of a confirmatory factor analysis (CFA) showed that the theoretically assumed unidimensional model fit the data adequately. According to a structural regression model testing the pattern of covariates, a strong correlation was observed with the Problematic Online Gaming Questionnaire (POGQ; Demetrovics et al., 2012), an instrument assessing a similar construct, and both instruments were moderately associated with psychiatric distress and weakly with gaming time, supporting the construct validity of the IGDT-10 (Király, Sleczka, et al., 2017). Previous instruments operationalizing the IGD criteria as proposed in the DSM-5 were either lengthier or had adopted the DSM-5 item-wording too closely, making the instrument less user-friendly, or did not fully cover all nine criteria. Accordingly, the comparative advantage of the IGDT-10 over the other short instruments (e.g., Lemmens et al., 2015; Pontes \& Griffiths, 2015) is its clear and user-friendly wording and its comprehensive coverage of all IGD criteria as proposed by the DSM-5.

Given that problematic gaming is a global phenomenon, at least across developed and developing countries, cross-cultural research is greatly needed. Furthermore, measurement invariance across gender is also important due to the considerable gender differences in video gaming habits and problematic gaming (Pápay et al., 2013; Rehbein, Kliem, Baier, Mößle, \& Petry, 2015). In order to conduct meaningful cross-cultural and gender comparisons, screening instruments need to demonstrate that they are psychometrically equivalent (i.e., measurement invariant). If invariance is not present, interpretation of mean scores and correlations between groups may be ambiguous. This is because lack of invariance suggests that, in the current context, true cultural or gender differences in the construct (IGD) may be confounded by changes in item functioning or variability in dimensionality. Failure to establish invariance would indicate the need for culturally or gender sensitive assessments and treatment. On the other hand, if invariance is present, it means that people of different cultures or genders interpret and respond to items in the same way.

Against this background, the aim of the present study was to explore the psychometric properties of the IGDT-10 across seven language-based samples (Czech, English-speaking, French-speaking, Hungarian, Persian [Iranian], Norwegian, and Spanish [Peruvian]) and to test the instrument's measurement invariance as a function of language and gender. To the best of the authors' knowledge, this is the first study to test gender and language invariance of an IGD screening instrument in a large international sample of more than 8,000 online gamers.

\section{Methods and materials}

\section{Participants and procedure}

The present study is part of a large cross-cultural research project exploring online gaming motives, problematic online gaming, and other psychological factors such as psychiatric symptoms and impulsivity among ten language-based samples: Czech $(n=496)$, English-speaking $(n=754)$, French-speaking $(n=421)$, Hungarian $(n=3924)$, Italian $(n=280)$, Korean ( $n=3040)$, Norwegian $(n=721)$, Persian (Iranian) $(n=791)$, Spanish (Peruvian) $(n=612)$, and Slovenian $(n=274)$. Countries of residence for the participants in each language-based sample are shown in Table 1. The present study uses seven of the 10 samples (i.e., Czech, 
English-speaking, French-speaking, Hungarian, Persian [Iranian], Norwegian ${ }^{1}$, and Spanish [Peruvian]) because data collection in the other three languages (i.e., Italian, Korean, and Slovenian) took place before or during the development of the IGDT-10. However, the methods of the entire research project are described in the present paper.

The same online questionnaire (with few changes; for details see Supplemental Table 1 among the Online Supplemental Materials) was used to collect data from online gamers in all aforementioned language-based samples. Survey questions were translated from English to the other languages using a standardized procedure (Beaton, Bombardier, Guillemin, \& Ferraz, 2000). Translation was conducted by researcher colleagues from the collaborating countries and back translated by another expert. Back translations were compared with the original English version and differences were discussed until a final consensus was reached. The final versions were shown to a small group of gamers who gave their opinions regarding the clarity and comprehension of the items.

The study protocol was the same for all languages and the same online platform hosted the questionnaires in each language, except for Korean and Spanish (Peruvian) versions where the collaborating researchers used their own online platforms and Persian (Iranian) version where another platform was provided by the lead researchers of this project due to technical issues. Data collection for the entire cross-cultural research project took place between 2011 and 2016. Unique data collection time frames are presented in Supplemental Table 1 among the Online Supplemental Materials. The cross-cultural research project was approved by the Institutional Review Board of the authors' institution and was performed in line with the Declaration of Helsinki.

Participants were recruited online via gaming-related websites, forums and socialnetworking sites (SNSs). The most popular online gaming websites and gamer groups on SNSs were identified. A call for participation was posted regularly in the "off topic" section of the forums, and on the news feed of the SNSs. In the call for participation, gamers were asked to visit a separate website and complete the questionnaire. Prior to filling out the questionnaire, all participants were informed about the goals of the study and the time needed to complete it (approximately 20 minutes). Participants were assured about confidentiality and anonymity, and their informed consent was obtained prior to study participation. To participate in the study, it was necessary to be 18 years or older. To encourage participation, incentives were offered, and these varied to be appropriate to the specific cultures and research groups. The incentives were typically material or financial prizes that one or more lucky participants could win in a drawing (see Supplemental Table 1 among the Online Supplemental Materials for more details about the incentives in each sample). According to the voluntary nature of participation, answering all survey questions was not mandatory. No personal information was collected or stored except for email addresses in those samples where incentives were offered (see Supplemental Table 1 among the Online Supplemental Materials). These email addresses were stored confidentially and were only used to contact the winners of the draws.

\footnotetext{
${ }^{1}$ The Norwegian sample was collected in three different time periods over the course of two and a half years (for details see Supplemental Table 1). The IGDT-10 was included in the survey only during the third data collection wave, therefore the Norwegian sample used in this study is only a subsample $(n=195)$ of the total Norwegian sample.
} 
However, there were a few exceptions in the recruitment process across cultures/languages. In the case of the Hungarian sample, a popular gaming magazine helped to promote the survey among their online readers and Facebook followers (for more details of the recruitment process see Király, Tóth, Urbán, Demetrovics, \& Maraz, 2017). In the case of the Peruvian sample, the online survey was promoted on the website and Facebook page of a large gaming event. Consequently, the Peruvian sample comprised mostly the participants of this gaming event (i.e., 'hard-core' gamers). Lastly, in the Korean case, data were collected by a market and opinion research company (Hankook Research, Inc.) using a pre-recruited panel through the Computer Aided Web Interview (CAWI) method. The target population included adults aged 20 to 49 years who played video games within one month prior to data collection. The panel was established in a way to resemble the Korean population along key demographic characteristics (i.e., gender, age, geographic location). Therefore, it comprised mostly 'casual' gamers and had a higher proportion of women than the other samples.

[INSERT TABLE 1 HERE]

\section{Measures}

The same online questionnaire battery was administered in all ten language-based samples. Some minor changes were made to improve the questionnaire battery or to adjust to the particular needs of the different samples. Supplemental Table 1 among the Online Supplemental Materials summarizes the measures used in each language-based sample. In the present study, only those measurement instruments that were used to test the validity and measurement invariance of the IGDT-10 across languages are described in detail.

Sociodemographic characteristics: Data concerning gender, age, country of residence and nationality, marital status, educational level, current education-related, and work-related status were collected.

Gaming time: Categories for weekly gaming time were the following: (1) "less than seven hours weekly (less than one hour a day)", (2) "7-14 hours weekly (1-2 hours per day)", (3) "15-28 hours weekly (2-4 hours per day)", (4) "29-42 hours weekly (4-6 hours per day)", and (5) "more than 42 hours weekly (more than 6 hours per day)".

Motives for Online Gaming Questionnaire (MOGQ; Demetrovics et al., 2011). The MOGQ is a 27-item self-report measure that assesses the full range of motives for online gaming. These are: social (e.g., “... because I can meet many different people”), escape (e.g., "... to forget about unpleasant things or offences"), competition (e.g., "... because I like to win”), skill development (e.g., “... because it improves my skills”), coping (e.g., “... because it helps me get rid of stress"), fantasy (e.g., "... to be somebody else for a while"), and recreation (e.g., "... for recreation"). The instrument uses a 5-point Likert scale from "never" to "almost always/always", with higher scores indicating stronger motivations. Internal consistencies for the present sample were excellent, ranging from .76 (recreation) to .91 (skill development).

Problematic Online Gaming Questionnaire (POGQ; Demetrovics et al., 2012). The POGQ is an 18-item scale assessing problematic online gaming, showing good psychometric properties in both adult and adolescent samples (Pápay et al., 2013). The scale comprises six factors: social isolation (e.g., "How often do you choose gaming over going out with someone?"), interpersonal conflicts (e.g., "How often do the people around you complain that you are gaming too much?"), overuse (e.g., "How often do you unsuccessfully try to reduce the 
time you spend on gaming?), withdrawal (e.g., "How often do you get irritable or upset when you cannot play?"), immersion (e.g., "How often are you so immersed in gaming that you forget to eat?"), and preoccupation (e.g., "How often do you daydream about gaming?"). Participants respond on a five-point Likert scale (1= "never", 5 = "almost always/always"), with higher scores indicating higher risk for problematic online gaming. The internal consistencies of the scale were excellent on each language-based sample $\left(\alpha_{\text {Hungarian }}=.90 ; \alpha_{\text {Persian (Iranian })}=.94 ; \alpha\right.$ English $=.89 ; \alpha_{\text {French }}=.89 ; \alpha_{\text {Norwegian }}=.90 ; \alpha_{\text {Czech }}=.90 ; \alpha_{\text {Spanish }}($ Peruvian $\left.)=.94\right)$.

Ten-Item Internet Gaming Disorder Test (IGDT-10; Király, Sleczka, et al., 2017). The IGDT-10 assesses past-year IGD, with 10 items comprising the nine diagnostic criteria of IGD based on DSM-5 (American Psychiatric Association, 2013) (e.g., "Have you ever in the past 12 months unsuccessfully tried to reduce the time spent on gaming?"). It was developed theoretically via experts' discussion. To retain high content validity, the nine DSM-5 criteria of IGD were strictly followed, while also taking into account Petry et al.'s (2014) recommendations regarding item operationalization. Given the complexity of the final IGD criterion ("Has jeopardized or lost a significant relationship, job, or educational or career opportunity because of participation in Internet games"), Király et al. (2017) operationalized this criterion via two items to avoid the use of double-barreled questions. Respondents indicated the frequency of each statements ( $0=$ "never"; 1 = "sometimes"; 2 = "often"). However, during further analyses, the IGDT-10 scores were recoded to resemble the dichotomous structure of the DSM-5 criteria of IGD. Responses "never" and "sometimes" were coded as the criterion was not met ( 0 point), while "often" was evaluated as the criterion was met (1 point). Because two items referred to the final DSM-5 criterion (Items 9 and 10), they were combined during the scoring. Responding with "often" to any of the two items or both generated one point in the scoring. Therefore, the composite score of IGDT-10 ranged from 0 to 9 . A score of five or more points indicates clinically relevant cases according to the DSM-5 (American Psychiatric Association, 2013). Therefore, this threshold was used to define the proportion of participants that met the cut-off score on the IGDT-10 (the possible risk group). Nevertheless, the present study avoids using the term 'prevalence' due to the convenience nature of the sample. The English version of the IGDT-10, along with the translations in Hungarian, Persian (Iranian), French, Norwegian, Czech, and Spanish (Peruvian), can be seen in Supplemental Table 3-9 among the Online Supplemental Materials. The instrument has also been adapted to Chinese language and showed good psychometric properties among adolescents in Taiwan (Chiu, Pan, \& Lin, 2018).

Brief Symptom Inventory (BSI; Derogatis, 1975). The BSI assesses psychiatric distress comprising 53 items on nine self-reported clinically relevant psychological symptoms: psychoticism (e.g., "The idea that someone else can control your thoughts"), paranoid ideation (e.g., "Feeling others are to blame for most of your troubles"), phobic anxiety (e.g., "Feeling afraid in open spaces"), hostility (e.g., "Feeling easily annoyed or irritated"), anxiety (e.g., "Nervousness or shakiness inside"), depression (e.g., "Thoughts of ending your life"), interpersonal sensitivity (e.g., "Your feelings being easily hurt"), compulsion-obsession (e.g., "Trouble remembering things"), and somatization (e.g., "Faintness or dizziness"). Participants indicated on a five-point Likert scale ( $0=$ "not at all", $4=$ "extremely") how much they were bothered by psychological symptoms during the past seven days. In the present study, a summarized index, namely the Global Severity Index (GSI) was used to assess the level of 
general distress. Higher GSI scores indicated stronger psychiatric distress. The internal consistencies of the scale were excellent in each language-based samples $\left(\alpha_{\text {Hungarian }}=.96 ; \alpha_{\text {Persian }}\right.$ $($ Iranian $\left.)=.98 ; \alpha_{\text {English }}=.97 ; \alpha_{\text {French }}=.96 ; \alpha_{\text {Norwegian }}=.97 ; \alpha_{\text {Czech }}=.96\right)$. In the case of the Peruvian sample, only the depression and anxiety subscales were assessed, these subscales also showed good internal consistencies $\left(\alpha_{\text {depression }}=.87 ; \alpha_{\text {anxiety }}=.89\right)$.

Barratt Impulsiveness Scale (BIS; Kapitány-Fövény et al., 2018; Patton, Stanford, \& Barratt, 1995). The BIS-21 assesses impulsivity across 21 items comprising three components of impulsivity: self-control (reversed, e.g., "I plan tasks carefully."), impulsive behavior (e.g., "I do things without thinking."), and restlessness (e.g., "I am restless at the theater or lectures."). Participants indicate their responses on a five-point Likert scale ( 1 = "rarely/never", $4=$ "almost always/always"), with higher scores indicating higher level of impulsivity. The internal consistencies of this scale were good on each language-based sample $\left(\alpha_{\text {Hungarian }}=.80 ; \alpha_{\text {Persian }}\right.$ $($ Iranian $)=.82 ; \alpha_{\text {English }}=.82 ; \alpha_{\text {French }}=.79 ; \alpha_{\text {Norwegian }}=.79 ; \alpha_{\text {Czech }}=.84 ; \alpha_{\text {Spanish }}($ Peruvian $\left.)=.82\right)$.

\section{Statistical analyses}

Statistical analyses were performed using SPSS 22 and Mplus 7.3 (Muthén \& Muthén, 1998-2012). Only fully or almost fully completed questionnaires were analyzed (i.e., cases with less than $10 \%$ missing values per scales). Missing data were treated with Full Information Maximum Likelihood (FIML) method in Mplus. Confirmatory factor analysis (CFA) was used to assess the dimensionality of the scale with the weighted least squares mean- and varianceadjusted (WLSMV) estimator which was demonstrated to outperform maximum likelihood for ordered-categorical indicators with five or fewer answer categories (Bandalos, 2014; Finney \& DiStefano, 2006). The IGDT-10 items were analyzed in each language and in each gender in order to check the adequacy of the fit of the one-factor model.

Model fit was determined by assessing multiple goodness-of-fit indices (Guttman, 1945; $\mathrm{Hu} \&$ Bentler, 1999) based on the following thresholds (Guttman, 1945; Hu \& Bentler, 1999; Schermelleh-Engel, Moosbrugger, \& Müller, 2003): the Comparative Fit Index (CFI; $\geq .95$ for good model fit, $\geq .90$ for acceptable model fit), the Tucker-Lewis Index (TLI ; $\geq .95$ for good model fit, $\geq .90$ for acceptable model fit), and the Root Mean-Square Error of Approximation (RMSEA; $\leq .05$ for good model fit, $\leq .08$ for acceptable model fit) with its $90 \%$ confidence intervals ( $90 \% \mathrm{CIs}$ ). Factor loadings $\geq 0.40$ were considered to be salient (Brown, 2015).

Measurement invariance between language (Hungarian, Persian, English, French, Norwegian, Czech, and Spanish) and gender (male and female) groups was tested using multiple-group CFAs (Jellesma, Meerum Terwogt, Reijntjes, Rieffe, \& Stegge, 2005; Muthén \& Muthén, 2013; Przybylski, Murayama, DeHaan, \& Gladwell, 2013) with a convenience feature of Mplus to run the analyses with delta parameterization (as the default parameterization in Mplus) (Muthén \& Muthén, 1998-2017). Measurement invariance was tested in all language groups in one model (omnibus test of invariance). In the first step, the models were estimated freely for each language and gender subgroups (in fact, this step was the same as the aforementioned CFA). In the second step, models with increasingly constrained parameters were estimated: (1) factor loadings and thresholds were freely estimated across groups (configural invariance), and (2) factor loadings and thresholds were set to be equal across groups (scalar invariance). The assessment of metric invariance (i.e., only factor loadings were set to be equal across groups) was not allowed for weighted least squares and dichotomous 
variables in Mplus because this model was not identified due to residual variances or scale factors being allowed to vary across groups (Muthén \& Muthén, 2013). When comparing the increasingly constrained models, due to the oversensitivity of the chi-square difference test (Marsh, Hau, \& Grayson, 2005), relative change in fit indices (i.e., $\triangle$ CFI and $\triangle$ RMSEA) were also examined. A change of $\geq-.01$ in the CFI and a change of $\geq .015$ in the RMSEA indicates non-invariance (Chen, 2007; Cheung \& Rensvold, 2002).

Internal consistencies were assessed by Cronbach's alpha coefficient $(\alpha)$, which was considered 'acceptable' if the values were $\geq .70$ and 'good' if the values were $>.80$ (Brown, 2015). Given the severe criticisms regarding the limited usefulness of Cronbach's $\alpha$ as a reliability estimate (Sijtsma, 2009), composite reliability (CR) was also calculated, which can better represent the construct as it takes into account the factor loadings with their respective measurement errors. CR was assessed based on the formula of Raykov (2018), and is considered acceptable above .60 and good above .70 (Bandalos, 2014). Finally, to test the construct validity of the IGDT-10, Pearson product-moment correlations were examined with related scales (i.e., POGQ, BSI, BIS-21) and variables (i.e., weekly gaming time).

\section{Results}

Descriptive statistics

Cases with severe incompleteness (i.e., cases with more than $10 \%$ missing values per scale) and inconsistencies (e.g., inconsistencies in demographic characteristics such as age and number of completed school years, or similar responses given to direct and reversed items in a scale), as well as univariate outliers (e.g., age, education), were excluded in all samples. Basic demographic characteristics (gender ratio, mean age, completed years in education, relationship status, ongoing studies, working status), weekly time spent gaming of respondents, and frequency of gaming on personal computer, video game console and mobile device can be seen in Table 2.

Most of the gamers in each sample were male. The Iranian and French-speaking samples had the highest percentage of women (approx. 25\%) while the Peruvian sample had the lowest percentage (1.3\%). The mean age of participants in all samples was above 20 years. On average, Peruvian gamers were the youngest, whereas Czech players were the oldest. All samples had a majority of individuals being single. The Peruvian sample had the highest proportion of single gamers and the lowest proportion of married gamers. Gamers studying at the time of data collection outnumbered those having a full-time job except for the Czech sample in which this proportion was reversed. The Iranian and the Peruvian samples had the highest proportions of students. The distribution of gaming time followed a normal distribution pattern in six of the seven samples. The only exception was the Iranian sample in which the distribution was skewed severely to the right toward the lower amount of gaming time (the skewness value was 1.41 for the Iranian sample whereas it ranged from -.02 to .36 in the other samples). The proportion of gamers playing more than two hours on average day per day (including the "15-28 hours weekly (2-4 hours per day)", "29-42 hours weekly (4-6 hours per day)", and "more than 42 hours weekly (more than 6 hours per day)" response options) was highest in the Peruvian sample.

[INSERT TABLE 2 HERE] 
Structural analysis and measurement invariance across language and gender

To test the dimensionality of the IGDT-10 scale, separate CFAs were performed on the nine dichotomous items (recoded from the original ten items; see the Measures section) in all seven language-based samples and for males and females overall. A one-factor solution was tested based on previous empirical and theoretical evidence (American Psychiatric Association, 2013; Király, Sleczka, et al., 2017). Goodness-of-fit results are presented in Table 3. The CFA models were acceptable in all language samples and for males and females (CFIs were $\geq .95$, TLIs were $>.93$ and RMSEAs were $<.05)$. All factor loadings were salient $(\geq 0.40)$, positive, and statistically significant $(p<.001)$ in each language and across both genders (see Table 4 ).

Measurement invariance for language was tested across all language-based samples (Hungarian, Persian [Iranian], English, French, Norwegian, Czech, and Spanish [Peruvian]) in one model (omnibus test of invariance). Configural and scalar invariance models were estimated. Although the $\Delta \chi^{2}$ test was significant, other model fit indices did not reach or surpass the recommended cut-off values of -.01 for $\triangle$ CFI and .015 for $\triangle$ RMSEA ( $\Delta$ CFI was -.002 and $\triangle$ RMSEA was -.002), supporting scalar invariance of the latent means in the one-factor model (see Table 3).

Finally, configural and scalar invariance models were estimated for males and females. The $\Delta \chi^{2}$ test was not significant ( $p=.486$ ), indicating support for gender invariance on the level of scalar invariance, in line with the other model fit indices, which did not reach or surpass the recommended cut-off values $(\triangle \mathrm{CFI}=.004 ; \Delta \mathrm{RMSEA}=-.006)$ (see Table 3 ). In other words, males and females interpret and respond to the IGDT-10 items in the same way.

[INSERT TABLE 3 HERE]

Reliability, descriptive statistics, and proportions of each sample meeting the cut-off score on the IGDT-10

Reliability indices and descriptive statistics of the IGDT-10 in all samples are presented in Table 4. Cronbach alpha coefficients ranged from .62 to .75 in the case of the nine dichotomous items and were above the acceptable limit in the case of the original 10 items with three response options. Moreover, CRs were acceptable indicating that the IGDT-10 is a reliable measure in each language-based sample. Preoccupation was the most frequently endorsed criterion followed by escape and continuation, while withdrawal, giving up other activities and deception were the least endorsed criteria across majority of language-based and gender-based samples. The proportions of each sample meeting the cut-off score on the IGDT-10 were significantly higher for males than females $\left(4.24 \%\right.$ and $2.62 \%$, respectively; $\chi^{2}=4.1, p=.042$, $\mathrm{OR}=0.61,95 \% \mathrm{CI}=0.37-0.99$ ). Furthermore, these proportions varied between $1.61 \%$ in the Norwegian and $4.48 \%$ in the English-speaking sample (comprising mostly gamers from the USA, UK, Canada and Australia) with one exception. The Spanish-speaking (Peruvian) sample had a particularly high proportion of those meeting the cut-off score $(13.71 \%)$. However, due to the convenience nature of the sample, these proportions likely do not reflect true prevalence estimates of population-based samples and may overestimate cases based on the sampling strategy, therefore should be treated cautiously. Nevertheless, they could be useful for designing research in the future on similar samples.

[INSERT TABLE 4 HERE] 


\section{Construct validity}

Correlations were calculated on the basis of the total sample because similar correlational patterns were observed in each language-based subgroup and both genders (see Table 5). The language specific correlational matrix is available as a supplemental material (see Supplemental Table 2 among the Supplemental Online Materials). The IGDT-10 had a strong positive association with the POGQ and moderate association with weekly gaming time, supporting the criterion validity of the IGDT-10. Both the IGDT-10 and the POGQ were positively and moderately related with the level of psychiatric distress (GSI) and impulsivity (BIS-21) supporting the construct validity of the IGDT-10.

[INSERT TABLE 5 HERE]

\section{Discussion}

The present study tested the psychometric properties of the Ten-Item Internet Gaming Disorder Test (IGDT-10), an instrument that assesses IGD as defined in the DSM-5, across seven language-based samples (i.e., Czech, English, French, Hungarian, Persian [Iranian], Norwegian, and Spanish [Peruvian]). Additionally, the study investigated the measurement invariance of the instrument across language and gender groups. Consistent with previous empirical and theoretical evidence, the one-dimensional factor model provided a good fit to the data in each of the samples. Reliability indices (Cronbach alpha and composite reliability) were acceptable or good in each language-based group and across genders. Criterion and construct validity of the IGDT-10 was supported by its strong positive association with the POGQ and moderate relation with weekly gaming time, psychiatric distress, and impulsivity, associations with similar strengths according to previous studies (Baggio et al., 2016; Hyun et al., 2015; Lemmens et al., 2015; Starcevic, Berle, Porter, \& Fenech, 2011).

In terms of the measurement invariance analyses, results indicated support for both language and gender invariance across the groups on the level of scalar invariance. This means that gamers speaking the seven languages included in the present study, as well as male and female gamers interpreted and responded to the IGDT-10 items in the same way. Support for an instruments' measurement invariance across cultures and genders is important for meaningful comparisons of summarized scores and associations. If the measurement invariance of an instrument is not supported, differences in the means and associations across the groups may derive from methodological issues (e.g., differences in measurement and scaling) rather than differences in the underlying features being assessed. Such properties could then lead to inaccurate interpretations of findings. According to the present results, the IGDT-10 shows good psychometric properties in seven different language-based samples and appears suitable for making comparisons across languages and gender groups.

The proportions of each sample that met the cut-off score on the IGDT-10 were also obtained. According to the analyses, positive test results for problematic gaming varied between $1.61 \%$ and $4.48 \%$, except for the Peruvian sample where this proportion was particularly high $(13.71 \%)$. Proportions under $5 \%$ are consistent with prior reports and studies with representative adolescent and adult samples from Europe report similar prevalence estimates to those observed in the present study (Király et al., 2015). The high rate of Peruvian gamers meeting five or more IGD criteria was somewhat unexpected and it may be explained by the 
nature of the sample. This particular sample was recruited from participants attending a large gaming event, and accordingly, was comprised largely of young males who played video games intensively (highly engaged gamers). A possible explanation is that IGD criteria may be less useful for differentiating between highly engaged and problematic gamers (e.g., in specific online gamer samples with high proportions of engaged gamers) than in differentiating between non-problematic and problematic gamers in more heterogeneous samples (e.g., nationally representative adolescent samples), as suggested by a recent study by Deleuze and colleagues (2000). For instance, highly engaged gamers may also be preoccupied with gaming both on the behavioral and cognitive levels, but without experiencing problems. Alternatively, but not mutually exclusively, highly engaged gamers may lose interest in previous hobbies for a period of time especially when new commercial games are released or players make new friends in a game. Nevertheless, it is important to note that screening instruments such as the IGDT-10 cannot be used to establish a diagnosis for disorders with low prevalence rates because they are prone to incorrectly overestimate the number of problematic gamers (Maraz, Király, \& Demetrovics, 2015). Furthermore, mischievous responding may also inflate IGD prevalence rates (Przybylski, 2016). Reliable diagnoses can only be obtained via clinical interviews conducted by qualified professionals.

The present study has several limitations. First, all samples included in the study were self-selected convenience samples and therefore not necessarily representative of the cultures/languages to which they belong. As a consequence, caution should be exercised in extrapolating the findings to each country. Relatedly, the methods used for participant recruitment differed between the seven samples and yielded different sample sizes. Nevertheless, self-selection yielded specific highly engaged gamer samples (Khazaal et al., 2014) relevant to the focus of the present study. Second, given the self-report nature of the study, the data are vulnerable to social desirability and memory recall biases. Third, similar to the majority of research conducted in the field, the present study also suffers from the common method bias. Future studies should try to obtain behavioral data as well (e.g., in-game behavioral metrics) to validate survey data. However, this is a particularly difficult task, as ingame behavioral variables are usually game-specific (e.g., see Yee, Ducheneaut, Nelson, \& Likarish, 2011; Yee, Ducheneaut, Shiao, \& Nelson, 2012). Finally, it should be noted that several criteria assessed with the IGDT-10 have been debated by scholars in the field. Therefore, it is possible that the definition and operationalization of IGD may change over time, which may generate a need to revise assessment instruments such as the IGDT-10. In terms of future research directions, it would be useful to assess test-retest reliability, predictive validity, and clinical validity of the IGDT-10 in these and other cross-cultural contexts.

\section{Conclusion}

The major strength and novelty of this study is the investigation of language and gender invariance in a large international sample of 7,193 gamers. To the best of the present authors' knowledge, this is the first study of its kind that has provided evidence of invariance of a screening questionnaire for IGD across samples in seven different languages and countries from diverse regions including Europe, the Middle East, North America, and South America. In addition, the robust findings across multiple samples provide further support for the establishment of IGD as a new diagnostic category. 


\section{References}

Aarseth, E., Bean, A. M., Boonen, H., Michelle Colder Carras, Coulson, M., Das, D., . . Van Rooij, A. J. (2017). Scholars' open debate paper on the World Health Organization ICD11 Gaming Disorder proposal. Journal of Behavioral Addictions, 6(3), 267-270. doi: 10.1556/2006.5.2016.088

American Psychiatric Association. (2013). Diagnostic and Statistical Manual of Mental Disorders. 5th edition. Washington DC: American Psychiatric Association.

Andreassen, C. S., Torsheim, T., Brunborg, G. S., \& Pallesen, S. (2012). Development of a Facebook Addiction Scale. Psychological Reports, 110(2), 501-517. doi: 10.2466/02.09.18.pr0.110.2.501-517

Baggio, S., Dupuis, M., Studer, J., Spilka, S., Daeppen, J.-B., Simon, O., . . Gmel, G. (2016). Reframing video gaming and Internet use addiction: Empirical cross - national comparison of heavy use over time and addiction scales among young users. Addiction, 111(3), 513-522. doi: 10.1111/add.13192.

Bandalos, D. L. (2014). Relative performance of categorical diagonally weighted least squares and robust maximum likelihood estimation. Structural Equation Modeling, 21(1), 102116.

Bányai, F., Zsila, Á., Király, O., Maraz, A., Elekes, Z., Griffiths, M. D., . . . Demetrovics, Z. (2017). Problematic social media use: Results from a large-scale nationally representative adolescent sample. PLoS ONE, 12(1), e0169839.

Beaton, D. E., Bombardier, C., Guillemin, F., \& Ferraz, M. B. (2000). Guidelines for the process of cross-cultural adaptation of self-report measures. Spine, 25(24), 3186-3191.

Brown, T. A. (2015). Confirmatory factor analysis for applied research (second edition). New York, NY: Guilford Press.

Chen, F. F. (2007). Sensitivity of goodness of fit indexes to lack of measurement invariance. Structural Equation Modeling, 14, 464-504.

Cheung, G. W., \& Rensvold, R. B. (2002). Evaluating goodness-of-fit indexes for testing measurement invariance. Structural Equation Modeling, 9, 233-255.

Chiu, Y.-C., Pan, Y.-C., \& Lin, Y.-H. (2018). Chinese adaptation of the Ten-Item Internet Gaming Disorder Test and prevalence estimate of Internet gaming disorder among adolescents in Taiwan. Journal of Behavioral Addictions. doi: 10.1556/2006.7.2018.92

Demetrovics, Z., Király, O., Griffiths, M. D., Farkas, J., Kökönyei, G., Elekes, Z., . . Urbán, R. (2016). Psychometric Properties of the Problematic Internet Use Questionnaire Short-Form in a Nationally Representative Sample of Adolescents. PLoS ONE, 11(8), e0159409. doi: 10.1371/journal.pone.0159409

Demetrovics, Z., Szeredi, B., \& Rózsa, S. (2008). The three-factor model of internet addiction: the development of the Problematic Internet Use Questionnaire. Behavior Research Methods, 40(2), 563-574. doi: 10.3758/BRM.40.2.563

Demetrovics, Z., Urbán, R., Nagygyörgy, K., Farkas, J., Griffiths, M. D., Pápay, O., . . Oláh, A. (2012). The development of the Problematic Online Gaming Questionnaire (POGQ). PLoS ONE, 7(5), e36417. doi: 10.1371/journal.pone.0036417 
Demetrovics, Z., Urbán, R., Nagygyörgy, K., Farkas, J., Zilahy, D., Mervó, B., . . Harmath, E. (2011). Why do you play? The development of the Motives for Online Gaming Questionnaire (MOGQ). Behavior Research Methods, 43(3), 814-825.

Derogatis, L. R. (1975). Brief Symptom Inventory. Baltimore, MD: Clinical Psychometric Research.

Evren, C., Dalbudak, E., Topcu, M., Kutlu, N., Evren, B., \& Pontes, H. M. (2018). Psychometric validation of the Turkish nine-item Internet Gaming Disorder Scale-Short Form (IGDS9-SF). Psychiatry Research, 265, 349-354. doi: https://doi.org/10.1016/j.psychres.2018.05.002

Finney, S. J., \& DiStefano, C. (2006). Non-normal and categorical data in structural equation modeling. In G. R. Hancock \& R. D. Mueller (Eds.), Structural equation modeling: A second course (pp. 269-314). Charlotte, NC: Information Age Publishing.

Griffiths, M. D., Kuss, D. J., Lopez-Fernandez, O., \& Pontes, H. M. (2017). Problematic gaming exists and is an example of disordered gaming: Commentary on: Scholars' open debate paper on the World Health Organization ICD-11 Gaming Disorder proposal (Aarseth et al.). Journal of Behavioral Addictions, 6, 296-301. doi: 10.1556/2006.6.2017.037

Griffiths, M. D., van Rooij, A. J., Kardefelt-Winther, D., Starcevic, V., Király, O., Pallesen, S., . . Demetrovics, Z. (2016). Working towards an international consensus on criteria for assessing Internet Gaming Disorder: A critical commentary on Petry et al (2014). Addiction, 111(1), 167-175.

Guttman, L. (1945). A basis for analyzing test-retest reliability. Psychometrika, 10(4), 255-282.

Higuchi, S., Nakayama, H., Mihara, S., Maezono, M., Kitayuguchi, T., \& Hashimoto, T. (2017). Inclusion of gaming disorder criteria in ICD-11: A clinical perspective in favor: Commentary on: Scholars' open debate paper on the World Health Organization ICD11 Gaming Disorder proposal (Aarseth et al.). Journal of Behavioral Addictions, 6, 293295. doi: 10.1556/2006.6.2017.049

Hu, L., \& Bentler, P. M. (1999). Cutoff criteria for fit indexes in covariance structure analysis: Conventional criteria versus new alternatives. Structural Equation Modeling, 6(1), 155. doi: 10.1080/10705519909540118

Hyun, G. J., Han, D. H., Lee, Y. S., Kang, K. D., Yoo, S. K., Chung, U. S., \& Renshaw, P. F. (2015). Risk factors associated with online game addiction: A hierarchical model. Computers in Human Behavior, 48(0), 706-713. doi: http://dx.doi.org/10.1016/j.chb.2015.02.008

Jellesma, F. C., Meerum Terwogt, M., Reijntjes, A. H., Rieffe, C. J., \& Stegge, H. (2005). De vragenlijst Non-Productieve Denkprocessen voor Kinderen [Nonproductive Thoughts Questionnaire for Children: Worrying and rumination]. Kind en adolescent, 26, 171177.

Kapitány-Fövény, M., Urbán, R., Varga, G., Potenza, M., Griffiths, M. D., Székely, A., . . . Demetrovics, Z. (2018). The 21-item Barratt Impulsiveness Scale Revised (BIS-R-21): An alternative three-factor model. Manuscript in preparation.

Khazaal, Y., van Singer, M., Chatton, A., Achab, S., Zullino, D., Rothen, S., . . . Thorens, G. (2014). Does self-selection affect samples' representativeness in online surveys? An 
investigation in online video game research. Journal of Medical Internet Research, 16(7), e164. doi: 10.2196/jmir.2759

King, D. L., Haagsma, M. C., Delfabbro, P. H., Gradisar, M., \& Griffiths, M. D. (2013). Toward a consensus definition of pathological video-gaming: a systematic review of psychometric assessment tools. Clinical Psychology Review, 33(3), 331-342. doi: 10.1016/j.cpr.2013.01.002

Király, O., Choi, S.-W., Ramos-Diaz, J., Guevara-Cordero, C., Rahimi-Movaghar, A., Lukavska, K., . . . Demetrovics, Z. (2018). Do gaming motives mediate between psychiatric symptoms and problematic online gaming? A cross-cultural study. Journal of Behavioral Addictions, 7(Supplement 1), 90.

Király, O., \& Demetrovics, Z. (2017). Inclusion of Gaming Disorder in ICD has more advantages than disadvantages: Commentary on: Scholars' open debate paper on the World Health Organization ICD-11 Gaming Disorder proposal (Aarseth et al.). Journal of Behavioral Addictions, 6, 280-284. doi: 10.1556/2006.6.2017.046

Király, O., Griffiths, M. D., \& Demetrovics, Z. (2015). Internet gaming disorder and the DSM5: Conceptualization, debates, and controversies. Current Addiction Reports, 2(3), 254262. doi: 10.1007/s40429-015-0066-7.

Király, O., Nagygyörgy, K., Griffiths, M. D., \& Demetrovics, Z. (2014). Problematic online gaming. In K. Rosenberg \& L. Feder (Eds.), Behavioral addictions: Criteria, evidence and treatment (pp. 61-95). New York, NY: Elsevier.

Király, O., Sleczka, P., Pontes, H. M., Urbán, R., Griffiths, M. D., \& Demetrovics, Z. (2017). Validation of the Ten-Item Internet Gaming Disorder Test (IGDT-10) and evaluation of the nine DSM-5 Internet Gaming Disorder criteria. Addictive Behaviors, 64, 253-260. doi: 10.1016/j.addbeh.2015.11.005

Király, O., Tóth, D., Urbán, R., Demetrovics, Z., \& Maraz, A. (2017). Intense video gaming is not essentially problematic. Psychology of Addictive Behaviors, 31(7), 807-817. doi: 10.1037/adb0000316

Koronczai, B., Urbán, R., Kökönyei, G., Paksi, B., Papp, K., Kun, B., . . . Demetrovics, Z. (2011). Confirmation of the three-factor model of problematic internet use on off-line adolescent and adult samples. Cyberpsychology, Behavior, and Social Networking, 14, 657-664. doi: 10.1089/cyber.2010.0345

Kuss, D. J., Griffiths, M. D., \& Pontes, H. M. (2017). Chaos and confusion in DSM-5 diagnosis of Internet Gaming Disorder: Issues, concerns, and recommendations for clarity in the field. Journal of Behavioral Addictions, 6(2), 103-109. doi: 10.1556/2006.5.2016.062

Lafrenière, M.-A. K., Verner-Filion, J., \& Vallerand, R. J. (2012). Development and validation of the Gaming Motivation Scale (GAMS). Personality and Individual Differences, 53(7), 827-831. doi: http://dx.doi.org/10.1016/j.paid.2012.06.013

Lee, S.-Y., Choo, H., \& Lee, H. K. (2017). Balancing between prejudice and fact for Gaming Disorder: Does the existence of alcohol use disorder stigmatize healthy drinkers or impede scientific research? Commentary on "Scholars' open debate paper on the World Health Organization ICD-11 Gaming Disorder proposal”. Journal of Behavioral Addictions. doi: 10.1556/2006.6.2017.047

Lemmens, J. S., Valkenburg, P. M., \& Gentile, D. A. (2015). The Internet Gaming Disorder Scale. Psychological Assessment, 27(2), 567-582. doi: 10.1037/pas0000062 
Maraz, A., Király, O., \& Demetrovics, Z. (2015). The diagnostic pitfalls of surveys: if you score positive on a test of addiction, you still have a good chance not to be addicted. A response to Billieux et al. 2015. Journal of Behavioral Addictions, 4(3), 151-154. doi: 10.1556/2006.4.2015.026

Marsh, H. W., Hau, K.-T., \& Grayson, D. (2005). Goodness of fit evaluation. In A. MaydeuOlivares \& J. McArdle (Eds.), Contemporary psychometrics (pp. 275-340). Mahwah NJ: Erlbaum.

Monacis, L., Palo, V. d., Griffiths, M. D., \& Sinatra, M. (2016). Validation of the internet gaming disorder scale-short-form (IGDS9-SF) in an Italian-speaking sample. Journal of Behavioral Addictions, 5(4), 683-690.

Muthén, L. K., \& Muthén, B. O. (1998-2012). Mplus User's Guide. Seventh Edition. Los Angeles, CA: Muthén \& Muthén.

Muthén, L. K., \& Muthén, B. O. (1998-2017). Mplus User's Guide. Eight Edition. Los Angeles, CA: Muthén \& Muthén.

Muthén, L. K., \& Muthén, B. O. (2013). Version 7.1 Mplus Language Addendum.pdf. Retrieved from http://www.statmodel.com/download/Version7.1xLanguage.pdf

Müller, K. W., \& Wölfling, K. (2017). Both sides of the story: Addiction is not a pastime activity: Commentary on: Scholars' open debate paper on the World Health Organization ICD-11 Gaming Disorder proposal (Aarseth et al.). Journal of Behavioral Addictions, 6(2), 118-120. doi: 10.1556/2006.6.2017.038

Pápay, O., Urbán, R., Griffiths, M. D., Nagygyörgy, K., Farkas, J., Elekes, Z., . . Demetrovics, Z. (2013). Psychometric properties of the Problematic Online Gaming Questionnaire Short-Form (POGQ-SF) and prevalence of problematic online gaming in a national sample of adolescents. Cyberpsychology, Behavior, and Social Networking, 16(5), 340348. doi: 10.1089/cyber.2012.0484

Patton, J. H., Stanford, M. S., \& Barratt, E. S. (1995). Factor structure of the Barratt Impulsiveness Scale. Journal of Clinical Psychology, 51(6), 768-774.

Petry, N. M., Rehbein, F., Gentile, D. A., Lemmens, J. S., Rumpf, H. J., Mossle, T., . . O'Brien, C. P. (2014). An international consensus for assessing internet gaming disorder using the new DSM-5 approach. Addiction, 109(9), 1399-1406. doi: 10.1111/add.12457

Pontes, H. M., \& Griffiths, M. D. (2015). Measuring DSM-5 internet gaming disorder: Development and validation of a short psychometric scale. Computers in Human Behavior, 45, 137-143. doi: 10.1016/j.chb.2014.12.006

Pontes, H. M., \& Griffiths, M. D. (2016). Portuguese validation of the internet gaming disorder scale-short-form. Cyberpsychology, Behavior, and Social Networking, 19(4), 288-293.

Pontes, H. M., Macur, M., \& Griffiths, M. D. (2016). Internet gaming disorder among Slovenian primary schoolchildren: Findings from a nationally representative sample of adolescents. Journal of Behavioral Addictions, 5(2), 304-310.

Pontes, H. M., Stavropoulos, V., \& Griffiths, M. D. (2017). Measurement invariance of the internet gaming disorder scale-short-form (IGDS9-SF) between the United States of America, India and the United Kingdom. Psychiatry Research, 257, 472-478.

Przybylski, A. K. (2016). Mischievous responding in Internet Gaming Disorder research. PeerJ, 4, e2401. doi: 10.7717/peerj.2401 
Przybylski, A. K., Murayama, K., DeHaan, C. R., \& Gladwell, V. (2013). Motivational, emotional, and behavioral correlates of fear of missing out. Computers in Human Behavior, 29(4), 1841-1848.

Ryan, R. M., Rigby, C. S., \& Przybylski, A. (2006). The motivational pull of video games: A self-determination theory approach. Motivation and Emotion, 30(4), 347-363.

Rehbein, F., Kliem, S., Baier, D., Mößle, T., \& Petry, N. M. (2015). Prevalence of Internet Gaming Disorder in German adolescents: diagnostic contribution of the nine DSM - 5 criteria in a statewide representative sample. Addiction, 110(5), 842-851. doi: 10.1111/add.12849

Saunders, J. B., Hao, W., Long, J., King, D. L., Mann, K., Fauth-Buhler, M., . . Poznyak, V. (2017). Gaming disorder: Its delineation as an important condition for diagnosis, management, and prevention. Journal of Behavioral Addictions, 6(3), 271-279. doi: 10.1556/2006.6.2017.039

Schermelleh-Engel, K., Moosbrugger, H., \& Müller, H. (2003). Evaluating the fit of structural equation models: Tests of significance and descriptive goodness-of-fit measures. Methods of psychological research online, 8(2), 23-74.

Sijtsma, K. (2009). On the use, the misuse, and the very limited usefulness of Cronbach's alpha. Psychometrika, 74(1), 107.

Starcevic, V., Berle, D., Porter, G., \& Fenech, P. (2011). Problem video game use and dimensions of psychopathology. International Journal of Mental Health and Addiction, 9(3), 248-256. doi: 10.1007/s11469-010-9282-5

van den Eijnden, R. J., Lemmens, J. S., \& Valkenburg, P. M. (2016). The social media disorder scale. Computers in Human Behavior, 61, 478-487.

van Rooij, A. J., Van Looy, J., \& Billieux, J. (2017). Internet Gaming Disorder as a formative construct: Implications for conceptualization and measurement. Psychiatry and Clinical Neurosciences, 71, 445-458. doi: 10.1111/pcn.12404

World Health Organization. (2018). ICD-11 for Mortality and Morbidity Statistics. Retrieved 20 September, 2018, from https://icd.who.int/browse11/l-m/en

Yee, N., Ducheneaut, N., Nelson, L., \& Likarish, P. (2011). Introverted elves \& conscientious gnomes: the expression of personality in world of warcraft. Paper presented at the Proceedings of the SIGCHI Conference on Human Factors in Computing Systems.

Yee, N., Ducheneaut, N., \& Nelson, L. (2012). Online gaming motivations scale: development and validation. Paper presented at the Proceedings of the SIGCHI Conference on Human Factors in Computing Systems, New York.

Yee, N., Ducheneaut, N., Shiao, H. T., \& Nelson, L. (2012). Through the azerothian looking glass: mapping in-game preferences to real world demographics. Paper presented at the Proceedings of the SIGCHI Conference on Human Factors in Computing Systems. 
Table 1. Countries of residence for the survey participants

\begin{tabular}{|c|c|c|}
\hline Survey language & Country of residence & $\mathrm{n}(\%$ of participants) \\
\hline \multirow[t]{3}{*}{ Czech $(n=496)$} & Czech Republic & $438(88.3)$ \\
\hline & Slovakia & $42(8.5)$ \\
\hline & Others & $16(3.2)$ \\
\hline \multirow[t]{5}{*}{ English ( $\mathrm{n}=754)$} & United States of America & $448(59.4)$ \\
\hline & United Kingdom & $99(13.1)$ \\
\hline & Canada & $76(10.1)$ \\
\hline & Australia & $67(8.9)$ \\
\hline & Others & $64(8.5)$ \\
\hline \multirow[t]{3}{*}{ French-speaking $(n=421)$} & France & $294(69.8)$ \\
\hline & Belgium & $113(26.8)$ \\
\hline & Others & $14(3.4)$ \\
\hline \multirow{2}{*}{ Hungarian $(n=3924)$} & Hungary & 3764 (95.9) \\
\hline & Others & $160(4.1)$ \\
\hline \multirow[t]{2}{*}{ Italian $(\mathrm{n}=280)$} & Italy & $274(97.9)$ \\
\hline & Others & $6(2.1)$ \\
\hline Korean $(n=3040)$ & Republic of Korea & 3040 (100) \\
\hline \multirow[t]{2}{*}{ Norwegian $(\mathrm{n}=721)$} & Norway & $705(97.8)$ \\
\hline & Others & $16(2.2)$ \\
\hline Persian (n=791) & Iran & $791(100)$ \\
\hline Spanish $(\mathrm{n}=612)$ & Peru & $612(100)$ \\
\hline \multirow[t]{2}{*}{ Slovene $(\mathrm{n}=274)$} & Slovenia & $271(98.9)$ \\
\hline & Others & $3(1.1)$ \\
\hline
\end{tabular}


Table 2. Descriptive statistics of the samples

\begin{tabular}{|c|c|c|c|c|c|c|c|c|}
\hline Demographics & $\begin{array}{l}\text { Total sample } \\
\qquad \begin{array}{c}\mathrm{N}=7682- \\
7714)\end{array}\end{array}$ & $\begin{array}{c}\text { Hungarian } \\
(\mathrm{n}=3906-3924)\end{array}$ & $\begin{array}{c}\text { Persian } \\
(\text { Iranian }) \\
(\mathrm{n}=782-791)\end{array}$ & $\begin{array}{c}\text { English } \\
(\mathrm{n}=754-751)\end{array}$ & $\begin{array}{c}\text { French } \\
(\mathrm{n}=417-421)\end{array}$ & $\begin{array}{c}\text { Norwegian } \\
(\mathrm{n}=193-195)\end{array}$ & $\begin{array}{c}\text { Czech } \\
(\mathrm{n}=491-496)\end{array}$ & $\begin{array}{c}\text { Spanish } \\
\text { (Peruvian) } \\
(\mathrm{n}=612)\end{array}$ \\
\hline Gender (males) & $6940(90.1 \%)$ & $3597(91.8 \%)$ & $592(75.4 \%)$ & $691(91.6 \%)$ & $317(75.3 \%)$ & $183(93.8 \%)$ & $459(92.5 \%)$ & $604(98.7 \%)$ \\
\hline Age range (years) & $18-84$ & $18-64$ & $18-50$ & $18-56$ & $18-73$ & $18-53$ & $18-84$ & $18-43$ \\
\hline Mean age in years (SD) & $24.2(5.9)$ & $24.3(5.9)$ & $23.4(4.8)$ & $24.0(5.9)$ & $25.8(7.9)$ & $23.8(5.7)$ & $26.7(6.7)$ & $21.3(3.3)$ \\
\hline $\begin{array}{l}\text { Education, number of completed } \\
\text { years, mean (SD) }\end{array}$ & $13.1(3.5)$ & $13.5(2.7)$ & $15.1(2.4)$ & $14.3(2.6)$ & $13.3(4.4)$ & $14.4(2.8)$ & $14.9(2.9)$ & N/A* \\
\hline Studying currently & $4206(54.7 \%)$ & $1924(49.2 \%)$ & $646(81.9 \%)$ & $371(49.2 \%)$ & $261(62.0 \%)$ & $103(53.4 \%)$ & $173(34.9 \%)$ & $459(75.0 \%)$ \\
\hline \multicolumn{9}{|l|}{ Working status } \\
\hline Not working & $2943(38.2 \%)$ & $1394(35.6 \%)$ & $465(58.8 \%)$ & $244(32.4 \%)$ & $188(44.7 \%)$ & $68(34.9 \%)$ & $82(16.5 \%)$ & $313(51.2 \%)$ \\
\hline Having a full-time job & $2826(36.7 \%)$ & $1690(43.1 \%)$ & $105(13.3 \%)$ & $294(39.0 \%)$ & $121(28.7 \%)$ & $55(28.2 \%)$ & $303(61.1 \%)$ & $79(12.9 \%)$ \\
\hline $\begin{array}{l}\text { Other (i.e., part-time job, } \\
\text { working on ad-hoc basis) }\end{array}$ & $1932(25.1 \%)$ & $833(21.3 \%)$ & $221(27.9 \%)$ & $216(28.6 \%)$ & $112(26.7 \%)$ & $52(26.6 \%)$ & $110(22.2 \%)$ & $220(35.9 \%)$ \\
\hline \multicolumn{9}{|l|}{ Marital status } \\
\hline Single & $4685(61.0 \%)$ & $2106(53.9 \%)$ & $606(76.8 \%)$ & $457(60.6 \%)$ & $248(58.9 \%)$ & $111(57.2 \%)$ & $304(61.3 \%)$ & $526(85.9 \%)$ \\
\hline In a relationship & $1419(18.5 \%)$ & $967(24.8 \%)$ & $86(10.9 \%)$ & $117(15.5 \%)$ & $61(14.5 \%)$ & $33(17.0 \%)$ & $33(6.7 \%)$ & $59(9.6 \%)$ \\
\hline Cohabitation or married & $1529(19.8 \%)$ & $808(20.7 \%)$ & $93(11.8 \%)$ & $175(23.2 \%)$ & $103(24.4 \%)$ & $49(25.3 \%)$ & $148(29.8 \%)$ & $27(4.4 \%)$ \\
\hline Other & $49(0.7 \%)$ & $25(0.6 \%)$ & $4(0.5 \%)$ & $2(0.3 \%)$ & $5(1.2 \%)$ & $1(0.5 \%)$ & $10(2.0 \%)$ & $0(0.0 \%)$ \\
\hline \multicolumn{9}{|l|}{ Weekly gaming time } \\
\hline Less than 7 hours weekly & $1579(20.5 \%)$ & $720(18.4 \%)$ & $464(59.3 \%)$ & $63(8.4 \%)$ & $99(23.5 \%)$ & $26(13.4 \%)$ & $81(16.3 \%)$ & $22(3.6 \%)$ \\
\hline 7-14 hours weekly & $1904(24.7 \%)$ & $1038(26.5 \%)$ & $144(18.4 \%)$ & $179(23.7 \%)$ & $124(29.5 \%)$ & $39(20.1 \%)$ & $132(26.6 \%)$ & $105(17.2 \%)$ \\
\hline 15-28 hours weekly & $2311(30.1 \%)$ & $1176(30.0 \%)$ & $83(10.6 \%)$ & $276(36.6 \%)$ & $123(29.2 \%)$ & $67(34.5 \%)$ & $171(34.5 \%)$ & $253(41.3 \%)$ \\
\hline 29-42 hours weekly & $1305(17.0 \%)$ & $670(17.1 \%)$ & $49(6.3 \%)$ & $167(22.1 \%)$ & $57(13.5 \%)$ & $43(22.2 \%)$ & $77(15.5 \%)$ & $159(26.0 \%)$ \\
\hline
\end{tabular}


More than 42 hours weekly

$590(7.7 \%)$

$310(7.9 \%)$

$42(5.4 \%)$

$69(9.2 \%)$

$18(4.3 \%)$

$19(9.8 \%)$

$32(6.5 \%)$

$73(11.9 \%)$

Note. Sample sizes for these analyses varied due to cases with missing values. *An ordinal scale of education was applied: $1.1 \%$ completed elementary school; $67.2 \%$ completed secondary school; $20.1 \%$ completed technical education; and $11.6 \%$ completed university. 
Table 3. Goodness-of-fit statistics and information criteria for the estimated models relating to the IGDT-10

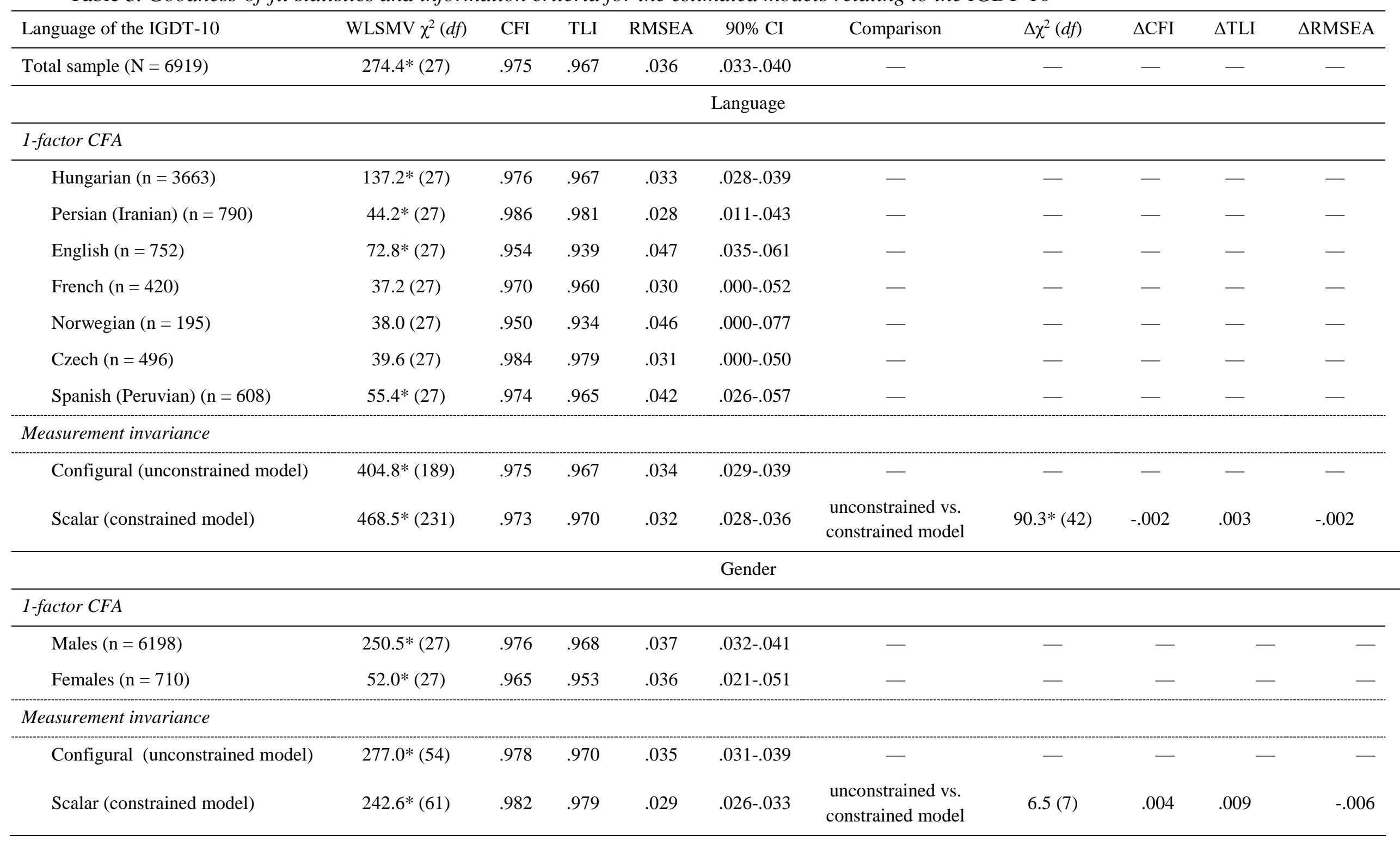


Note: IGDT-10 = Ten-Item Internet Gaming Disorder Test; CFA = confirmatory factor analysis; WLSMV = weighted least squares meanand variance-adjusted estimator; $\chi^{2}=$ Chi-square; $\mathrm{df}=$ degrees of freedom; CFI = comparative fit index; TLI = Tucker-Lewis Index; RMSEA = root-mean-square error of approximation; $90 \% \mathrm{CI}=90 \%$ confidence interval of the RMSEA; $\Delta \chi^{2}=$ Chi-square difference test based on the Mplus DIFFTEST function for WLSMV estimator; $\triangle \mathrm{CFI}=$ change CFI value; $\triangle \mathrm{RMSEA}=$ change in RMSEA value; Gender was coded as 1 for males (reference group) and 2 for females; Missing data was treated with the full information maximum likelihood (FIML) method $^{2} ; * p<.01$.

\footnotetext{
${ }^{2}$ We have also rerun the measurement invariance analyses across both language and gender groups using the listwise deletion method (using those cases only which had complete answers on all IGDT-10 items) and found very similar results. Variation in the total sample size between the two analyses was approximately $3 \%$.
} 
Table 4. Factor loadings, reliability indices, criterion endorsement, descriptive statistics relating to the IGDT-10 and proportions of each sample that met the cut-off score on the IGDT-10

\begin{tabular}{|c|c|c|c|c|c|c|c|c|c|c|}
\hline & & $\begin{array}{c}\text { Hungarian } \\
(\mathrm{n}=3542- \\
3663)\end{array}$ & $\begin{array}{c}\text { Persian } \\
\text { (Iranian) } \\
(\mathrm{n}=782- \\
790)\end{array}$ & $\begin{array}{c}\text { English- } \\
\text { speaking } \\
(\mathrm{n}=748- \\
752)\end{array}$ & $\begin{array}{c}\begin{array}{c}\text { French- } \\
\text { speaking } \\
(\mathrm{n}=417- \\
420)\end{array}\end{array}$ & $\begin{array}{c}\text { Norwegian } \\
(\mathrm{n}=193- \\
195)\end{array}$ & $\begin{array}{c}\text { Czech } \\
(\mathrm{n}=492- \\
496)\end{array}$ & $\begin{array}{c}\text { Spanish } \\
\text { (Peruvian) } \\
(\mathrm{n}=591-608)\end{array}$ & $\begin{array}{c}\text { Male } \\
(\mathrm{n}=6015- \\
6198)\end{array}$ & $\begin{array}{c}\text { Female } \\
(\mathrm{n}=687- \\
710)\end{array}$ \\
\hline \multirow{11}{*}{$\begin{array}{l}\text { Standardized } \\
\text { factor } \\
\text { loadings }\end{array}$} & Criterion 1 (preoccupation) & 0.57 & 0.70 & 0.53 & 0.44 & 0.55 & 0.67 & 0.58 & 0.60 & 0.54 \\
\hline & Criterion 2 (withdrawal) & 0.75 & 0.72 & 0.66 & 0.79 & 0.72 & 0.85 & 0.73 & 0.74 & 0.77 \\
\hline & Criterion 3 (tolerance) & 0.72 & 0.64 & 0.64 & 0.73 & 0.78 & 0.74 & 0.71 & 0.72 & 0.63 \\
\hline & Criterion 4 (loss of control) & 0.69 & 0.63 & 0.60 & 0.58 & 0.84 & 0.72 & 0.52 & 0.66 & 0.57 \\
\hline & Criterion 5 (giving up other activities) & 0.80 & 0.81 & 0.75 & 0.68 & 0.82 & 0.77 & 0.71 & 0.79 & 0.74 \\
\hline & Criterion 6 (continuation) & 0.82 & 0.77 & 0.92 & 0.69 & 0.62 & 0.87 & 0.72 & 0.80 & 0.76 \\
\hline & Criterion 7 (deception) & 0.72 & 0.80 & 0.58 & 0.63 & 0.52 & 0.80 & 0.71 & 0.72 & 0.76 \\
\hline & Criterion 8 (escape) & 0.64 & 0.61 & 0.55 & 0.52 & 0.65 & 0.52 & 0.50 & 0.60 & 0.57 \\
\hline & Criterion 9 (negative consequences) & 0.74 & 0.79 & 0.78 & 0.84 & 0.83 & 0.88 & 0.72 & 0.77 & 0.77 \\
\hline & Mean & 0.75 & 0.79 & 1.17 & 0.84 & 0.81 & 0.75 & 1.85 & 0.92 & 0.78 \\
\hline & SD & 1.31 & 1.45 & 1.56 & 1.28 & 1.31 & 1.40 & 2.00 & 1.49 & 1.31 \\
\hline \multirow{8}{*}{$\begin{array}{c}\text { Criterion } \\
\text { endorsement } \\
(\%)\end{array}$} & Criterion 1 (preoccupation) & 18.2 & 10.5 & 27.6 & 18.4 & 21.5 & 14.2 & 38.4 & 20.5 & 15.4 \\
\hline & Criterion 2 (withdrawal) & 2.8 & 4.8 & 4.9 & 3.1 & 2.6 & 2.4 & 9.8 & 3.9 & 3.4 \\
\hline & Criterion 3 (tolerance) & 4.0 & 6.6 & 13.2 & 10.3 & 9.2 & 10.7 & 20.5 & 7.9 & 6.1 \\
\hline & Criterion 4 (loss of control) & 6.1 & 8.9 & 6.4 & 5.3 & 4.1 & 4.4 & 14.3 & 7.0 & 6.4 \\
\hline & Criterion 5 (giving up other activities) & 4.3 & 7.2 & 4.9 & 3.1 & 4.6 & 5.7 & 19.3 & 6.0 & 6.4 \\
\hline & Criterion 6 (continuation) & 13.8 & 13.1 & 14.6 & 15.7 & 13.0 & 7.3 & 25.2 & 14.5 & 13.7 \\
\hline & Criterion 7 (deception) & 4.2 & 8.3 & 7.2 & 5.7 & 6.7 & 5.5 & 16.0 & 6.4 & 4.9 \\
\hline & Criterion 8 (escape) & 12.0 & 9.0 & 26.5 & 14.6 & 14.9 & 17.2 & 23.7 & 14.8 & 16.0 \\
\hline
\end{tabular}




\begin{tabular}{|c|c|c|c|c|c|c|c|c|c|c|}
\hline & Criterion 9 (negative consequences) & 9.7 & 10.7 & 11.3 & 7.2 & 9.8 & 7.5 & 19.1 & 11.0 & 6.0 \\
\hline \multirow{4}{*}{$\begin{array}{l}\text { Reliability } \\
\text { indices }\end{array}$} & $\alpha(10$ items, 3 response options $)$ & .79 & .86 & .77 & .77 & .79 & .78 & .79 & .81 & .80 \\
\hline & $\alpha$ (9 items, 2 response options) & .69 & .75 & .68 & .62 & .66 & .74 & .72 & .72 & .67 \\
\hline & CR (9 items, 2 response options) & .91 & .91 & .88 & .87 & .90 & .93 & .87 & .90 & .89 \\
\hline & CR (10 items, 3 response options) & .88 & .92 & .86 & .86 & .89 & .88 & .85 & .88 & .89 \\
\hline \multicolumn{2}{|c|}{$\begin{array}{l}\text { Proportions of each sample that met the cut-off score on } \\
\text { the IGDT-10 (95\% CI) }\end{array}$} & $\begin{array}{c}2.77 \% \\
(2.23-3.31)\end{array}$ & $\begin{array}{c}3.65 \% \\
(2.54-5.23)\end{array}$ & $\begin{array}{c}4.48 \% \\
(3.31-6.22)\end{array}$ & $\begin{array}{c}3.41 \% \\
(2.04-5.65)\end{array}$ & $\begin{array}{c}1.61 \% \\
(0.55-4.63)\end{array}$ & $\begin{array}{c}3.31 \% \\
(2.05-5.31)\end{array}$ & $\begin{array}{c}13.71 \% \\
(10.92-16.49)\end{array}$ & $\begin{array}{c}4.24 \% \\
(3.73-4.75)\end{array}$ & $\begin{array}{c}2.62 \% \\
(1.42-3.82)\end{array}$ \\
\hline
\end{tabular}

Note. All standardized factor loadings were significant at level $p<.001 . \mathrm{SD}=$ Standard deviation; $\alpha=\mathrm{Cronbach}$ 's alpha; CR $=$ composite reliability; The scale can be used either in the proposed way by dichotomizing the items to resemble the DSM-5 approach or in its original form by summarizing the scores given to the 10 items. Accordingly, the $\alpha$ and CR values are provided for both the original 10 items +3 response options and the 9 dichotomous items; IGDT-10 = Ten-Item Internet Gaming Disorder Test. 
Table 5. Correlations between the IGDT-10 and related variables

\begin{tabular}{|c|c|c|c|c|c|c|c|c|c|c|c|c|c|}
\hline Scales & Range & M & $\mathrm{SD}$ & 1 & 2 & 3 & 4 & 5 & 6 & 7 & 8 & 9 & 10 \\
\hline 1. IGDT-10 & $0-9$ & 0.90 & 1.47 & - & & & & & & & & & \\
\hline 2. POGQ total & $1-5$ & 2.15 & 0.66 & $.69 * *$ & - & & & & & & & & \\
\hline 3. POGQ social isolation & $1-5$ & 1.81 & 0.84 & $.56^{* *}$ & $.75^{* *}$ & - & & & & & & & \\
\hline 4. POGQ interpersonal conflicts & $1-5$ & 2.00 & 0.96 & $.46^{* *}$ & $.75^{* *}$ & $.46^{* *}$ & - & & & & & & \\
\hline 5. POGQ overuse & $1-5$ & 2.00 & 0.96 & $.49 * *$ & $.74 * *$ & $.47 * *$ & $.55^{* *}$ & - & & & & & \\
\hline 6. POGQ withdrawal & $1-5$ & 1.74 & 0.82 & $.59 * *$ & $.80 * *$ & $.57 * *$ & $.50 * *$ & $.49 * *$ & - & & & & \\
\hline 7. POGQ immersion & $1-5$ & 2.85 & 0.86 & $.45^{* *}$ & $.72 * *$ & $.42 * *$ & $.40 * *$ & $.44 * *$ & $.48 * *$ & - & & & \\
\hline 8. POGQ preoccupation & $1-5$ & 2.56 & 0.93 & $.52 * *$ & $.73 * *$ & $.47 * *$ & $.40 * *$ & $.35^{* *}$ & $.57 * *$ & $.48 * *$ & - & & \\
\hline 9. Weekly game time & $1-5$ & 2.66 & 1.20 & $.30 * *$ & $.33 * *$ & $.24 * *$ & $.27 * *$ & $.18 * *$ & $.23 * *$ & $.23 * *$ & $.32 * *$ & - & \\
\hline 10. Psychiatric symptoms (BSI) & $0-4$ & 0.58 & 0.59 & $.46^{* *}$ & $.47 * *$ & $.36 * *$ & $.31 * *$ & $.39 * *$ & $.42 * *$ & $.34 * *$ & $.29 * *$ & $.07 * *$ & - \\
\hline 11. Impulsivity (BIS-21) & $1-4$ & 1.91 & 0.39 & $.28 * *$ & $.33 * *$ & $.28 * *$ & $.24 * *$ & $.28 * *$ & $.29 * *$ & $.26 * *$ & $.15 * *$ & $.06 * *$ & $.40 * *$ \\
\hline
\end{tabular}

Note. IGDT-10 = Ten-Item Internet Gaming Disorder Test; POGQ = Problematic Online Gaming Questionnaire; BSI = Brief Symptom Inventory; BIS-21 = Barratt Impulsiveness Scale 21-item version; $* *=p<.01$ 
Supplemental Table 1. General information about the data collection and measures included in the cross-cultural survey

\begin{tabular}{|c|c|c|c|c|c|c|c|c|c|c|c|c|}
\hline $\begin{array}{c}\text { General } \\
\text { information/ } \\
\text { Variables }\end{array}$ & Scales & $\begin{array}{c}\text { Response } \\
\text { options }\end{array}$ & Hungarian & $\begin{array}{c}\text { Persian } \\
\text { (Iranian) }\end{array}$ & $\begin{array}{l}\text { English- } \\
\text { speaking }\end{array}$ & Korean & Italian & $\begin{array}{l}\text { French- } \\
\text { speaking }\end{array}$ & Slovenian & Norwegian & Czech & $\begin{array}{c}\text { Spanish } \\
\text { (Peruvian) }\end{array}$ \\
\hline $\begin{array}{l}\text { TIME OF } \\
\text { DATA } \\
\text { COLLECTI } \\
\text { ON }\end{array}$ & & & $\begin{array}{l}\text { August- } \\
\text { September } \\
2014\end{array}$ & $\begin{array}{c}\text { April- } \\
\text { November } \\
2016\end{array}$ & $\begin{array}{c}\text { January- } \\
\text { April } \\
2016\end{array}$ & $\begin{array}{c}17-28 \\
\text { March } \\
2014\end{array}$ & $\begin{array}{l}\text { June- } \\
\text { August } \\
2013\end{array}$ & $\begin{array}{c}\text { January- } \\
\text { August } \\
2016\end{array}$ & $\begin{array}{c}\text { June- } \\
\text { October } \\
2014\end{array}$ & $\begin{array}{c}1) \\
\text { September- } \\
\text { November } \\
2013 ; 2 \text { ) } \\
\text { February } \\
2015 ; 3) \\
\text { December } \\
2015 \text { - } \\
\text { February } \\
2016\end{array}$ & $\begin{array}{l}\text { August- } \\
\text { Novembe } \\
\text { r } 2016\end{array}$ & $\begin{array}{c}\text { April-July } \\
2015\end{array}$ \\
\hline $\begin{array}{l}\text { INCENTIV } \\
\mathrm{E}\end{array}$ & & & $\begin{array}{l}\text { shopping } \\
\text { voucher for } \\
\text { one winner } \\
\text { (value } \\
\text { approx. } \\
300 €)\end{array}$ & $\begin{array}{l}\text { cash for } \\
\text { three } \\
\text { winners } \\
\text { (value } \\
\text { approx. } \\
50 € \text { each) }\end{array}$ & $\begin{array}{c}\text { steam } \\
\text { games for } \\
\text { three } \\
\text { winners } \\
\text { (value } \\
\text { approx. } \\
100 € \\
\text { each) }\end{array}$ & $\begin{array}{c}\text { all } \\
\text { respondent } \\
\mathrm{s} \text { who } \\
\text { completed } \\
\text { the survey } \\
\text { received a } \\
\text { fee of } \\
\text { approx. } \\
1.56 €\end{array}$ & $\begin{array}{c}\text { no } \\
\text { incentives }\end{array}$ & $\begin{array}{c}\text { steam } \\
\text { games for } \\
\text { three } \\
\text { winners } \\
\text { (value } \\
\text { approx. } \\
100 € \text { each) }\end{array}$ & $\begin{array}{c}\text { no } \\
\text { incentives }\end{array}$ & $\begin{array}{l}\text { 1) no } \\
\text { incentives; } \\
\text { 2) steam } \\
\text { games for } \\
\text { one winner } \\
\text { (value } \\
50 €) ; 3 \text { ) } \\
\text { steam } \\
\text { games for } \\
\text { three } \\
\text { winners } \\
\text { (value } \\
\text { approx. } \\
100 € \text { each) }\end{array}$ & $\begin{array}{c}\text { shopping } \\
\text { voucher } \\
\text { for one } \\
\text { winner } \\
\text { (value } \\
\text { approx. } \\
300 € \text { ) }\end{array}$ & $\begin{array}{c}\text { three } \\
\text { gaming } \\
\text { headsets } \\
\text { for three } \\
\text { winners }\end{array}$ \\
\hline $\begin{array}{l}\text { Demographi } \\
\text { cs }\end{array}$ & & & + & + & + & + & + & + & + & + & + & + \\
\hline
\end{tabular}




\begin{tabular}{|c|c|c|c|c|c|c|c|c|c|c|c|c|}
\hline $\begin{array}{l}\text { Weekly } \\
\text { Internet } \\
\text { time }\end{array}$ & & & $+/-$ & + & + & - & - & + & - & $+/-$ & + & - \\
\hline $\begin{array}{l}\text { Problematic } \\
\text { internet use }\end{array}$ & $\begin{array}{l}\text { PIUQ-6 } \\
\text { /PIUQ- } \\
9\end{array}$ & & $\begin{array}{c}+ \\
\text { (PIUQ-6) }\end{array}$ & $\begin{array}{c}+ \\
\text { (PIUQ-9) }\end{array}$ & $\begin{array}{c}+ \\
\text { (PIUQ-9) }\end{array}$ & $\begin{array}{c}+ \\
\text { (PIUQ-9) }\end{array}$ & $\begin{array}{c}+ \\
\text { (PIUQ-6) }\end{array}$ & $\begin{array}{c}+ \\
\text { (PIUQ-9) }\end{array}$ & $\begin{array}{c}+ \\
\text { (PIUQ-6) }\end{array}$ & $\begin{array}{c}+ \\
\text { (PIUQ-9) }\end{array}$ & $\begin{array}{c}+ \\
\text { (PIUQ-9) }\end{array}$ & $\begin{array}{c}+ \\
\text { (PIUQ-6) }\end{array}$ \\
\hline $\begin{array}{l}\text { Online } \\
\text { activities } \\
\text { (e.g., SNS, } \\
\text { chat, porn, } \\
\text { shop) }\end{array}$ & & & + & - & - & - & - & - & - & - & - & - \\
\hline $\begin{array}{l}\text { Problematic } \\
\text { social } \\
\text { networking } \\
\text { sites use }\end{array}$ & BSMAS & & + & - & - & - & - & - & - & - & - & - \\
\hline $\begin{array}{l}\text { Weekly } \\
\text { gaming time }\end{array}$ & & & + & + & + & + & + & + & + & + & + & + \\
\hline \multirow{6}{*}{ Gaming type } & & RPG & + & + & + & + & + & + & + & + & + & + \\
\hline & & FPS & + & + & + & + & + & + & + & + & + & + \\
\hline & & RTS & + & + & + & + & + & + & + & + & + & + \\
\hline & & TBS & - & + & + & - & - & + & - & + & + & - \\
\hline & & MOBA & - & + & + & - & - & + & - & + & + & + \\
\hline & & Other & + & + & + & + & + & + & + & + & + & + \\
\hline \multirow[t]{2}{*}{$\begin{array}{l}\text { Gaming } \\
\text { platform } \\
\text { (PC, console, } \\
\text { mobile) } \\
\end{array}$} & & & $(+)$ & + & + & - & - & + & - & + & + & - \\
\hline & MOGQ & & + & + & + & + & + & + & + & + & + & + \\
\hline
\end{tabular}




\begin{tabular}{|c|c|c|c|c|c|c|c|c|c|c|c|}
\hline \multirow{3}{*}{$\begin{array}{l}\text { Gaming } \\
\text { motives }\end{array}$} & GAMS & + & + & + & + & + & + & - & + & + & + \\
\hline & \begin{tabular}{|l|} 
Yee's \\
motivat \\
ion \\
scale
\end{tabular} & + & - & - & + & + & - & - & $+/-$ & - & + \\
\hline & PENS & + & + & + & + & + & + & - & + & + & + \\
\hline \multirow{2}{*}{$\begin{array}{l}\text { Problematic } \\
\text { online } \\
\text { gaming }\end{array}$} & POGQ & + & + & + & + & + & + & + & + & + & + \\
\hline & $\begin{array}{l}\text { IGDT- } \\
10\end{array}$ & + & + & + & - & - & + & - & $+/-$ & + & + \\
\hline $\begin{array}{l}\text { Psychiatric } \\
\text { symptoms }\end{array}$ & BSI & + & + & + & + & + & + & + & + & + & $(++)$ \\
\hline Impulsivity & BIS-21 & + & + & + & + & + & + & + & + & + & + \\
\hline
\end{tabular}

Note. + : included in the questionnaire, -: not included in the questionnaire; +/-: included only in the questionnaire for a part of the sample; $(+)$ : included in the questionnaire but assessed differently; (++) only depression and anxiety subscales were included. SNS = social networking site; RPG = role playing game; FPS = first person shooter; RTS: real time strategy; TBS = turn-based strategy; MOBA = multiplayer battle arena. BIS-21 = Barratt's Impulsivity Scale, 21-item version (Patton, Stanford, \& Barratt, 1995; Kapitány-Fövény, et al., 2018); BSI = Brief Symptom Inventory (Derogatis, 1975); BSMAS = Problematic Social Networking Sites use (Andreassen, Torsheim, Brunborg, \& Pallesen, 2012; Bányai et al., 2017). GAMS = Gaming Motives Scale (Lafrenière, Verner-Filion, \& Vallerand, 2012); IGDT-10 = Ten-Item Internet Gaming Disorder Test (Király et al., 2017); MOGQ = Motives for Online Gaming Questionnaire (Demetrovics et al., 2011). PENS = Player Experience of Need Satisfaction (Ryan, Rigby, \& Przybylski, 2006); PIUQ-6/PIUQ-9 = Problematic Internet Use Questionnaire (6-item and 9-item versions, respectively) (Demetrovics et al., 2016; Demetrovics, Szeredi, \& Rózsa, 2008; Koronczai et al., 2011); POGQ = Problematic Online Gaming Questionnaire (Demetrovics et al., 2012); Yee's motivation scale (Yee, Ducheneaut, \& Nelson, 2012). 
Supplemental Table 2. Language specific correlations between the IGDT-10 and related variables

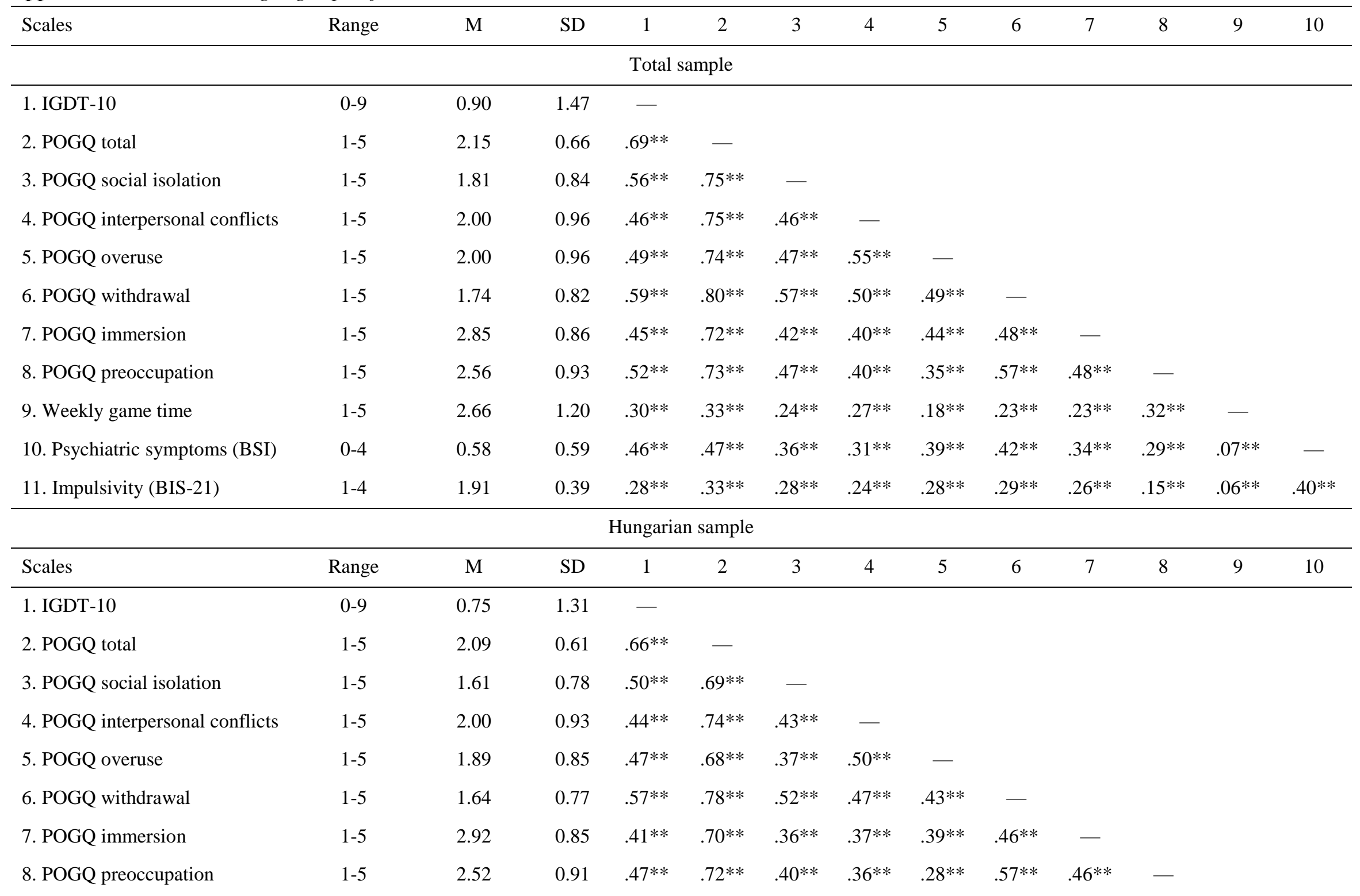




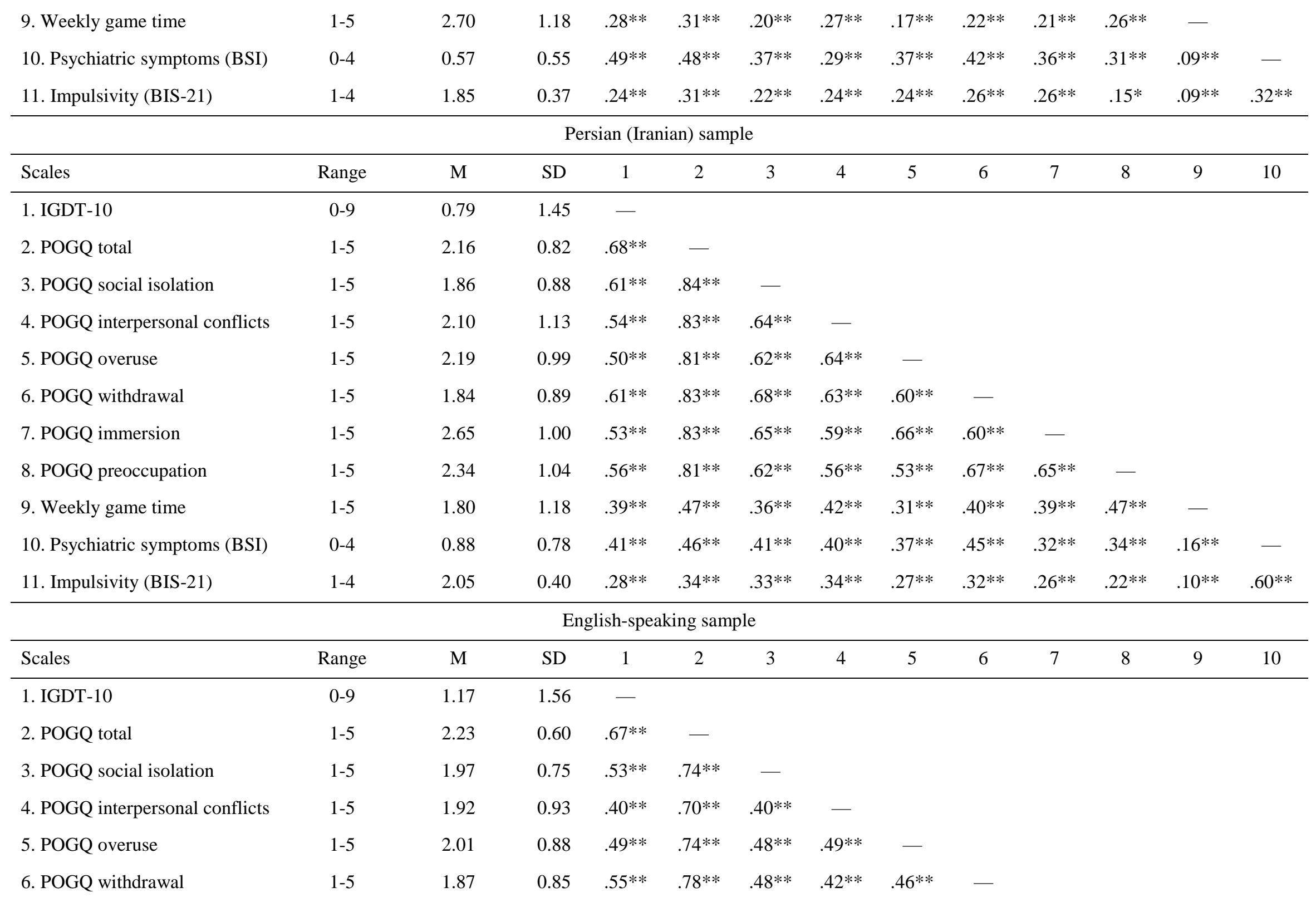




\begin{tabular}{|c|c|c|c|c|c|c|c|c|c|c|c|c|c|}
\hline 7. POGQ immersion & $1-5$ & 2.82 & 0.78 & $.46 * *$ & $.69 * *$ & $.44 * *$ & $.30 * *$ & $.44 * *$ & $.44 * *$ & - & & & \\
\hline 8. POGQ preoccupation & $1-5$ & 2.81 & 0.84 & $.48 * *$ & $.65^{* *}$ & $.40 * *$ & $.29 * *$ & $.24 * *$ & $.50 * *$ & $.38 * *$ & - & & \\
\hline 9. Weekly game time & $1-5$ & 3.00 & 1.08 & $.29 * *$ & $.28 * *$ & $.23^{* *}$ & $.19 * *$ & $.17 * *$ & $.20 * *$ & $.18 * *$ & $.23 * *$ & - & \\
\hline 10. Psychiatric symptoms (BSI) & $0-4$ & 0.60 & 0.65 & $.54 * *$ & $.47 * *$ & $.37 * *$ & $.25^{* *}$ & $.41 * *$ & $.39 * *$ & $.40 * *$ & $.23 * *$ & $.15^{* *}$ & - \\
\hline 11. Impulsivity (BIS-21) & $1-4$ & 1.98 & 0.41 & $.39 * *$ & $.34 * *$ & $.23 * *$ & $.19 * *$ & $.34 * *$ & $.27 * *$ & $.30 * *$ & $.17 * *$ & $.13 * *$ & $.49 * *$ \\
\hline \multicolumn{14}{|c|}{ French-speaking sample } \\
\hline Scales & Range & M & $\mathrm{SD}$ & 1 & 2 & 3 & 4 & 5 & 6 & 7 & 8 & 9 & 10 \\
\hline 1. IGDT-10 & $0-9$ & 0.84 & 1.28 & - & & & & & & & & & \\
\hline 2. POGQ total & $1-5$ & 2.16 & 0.58 & $.65^{* *}$ & - & & & & & & & & \\
\hline 3. POGQ social isolation & $1-5$ & 1.94 & 0.71 & $.47 * *$ & $.70 * *$ & - & & & & & & & \\
\hline 4. POGQ interpersonal conflicts & $1-5$ & 1.80 & 0.81 & $.39 * *$ & $.65^{* *}$ & $.33^{* *}$ & - & & & & & & \\
\hline 5. POGQ overuse & $1-5$ & 2.01 & 0.85 & $.47 * *$ & $.71 * *$ & $.39 * *$ & $.48 * *$ & - & & & & & \\
\hline 6. POGQ withdrawal & $1-5$ & 1.97 & 0.82 & $.57 * *$ & $.79 * *$ & $.51 * *$ & $.37 * *$ & $.45 * *$ & - & & & & \\
\hline 7. POGQ immersion & $1-5$ & 2.90 & 0.82 & $.44 * *$ & $.70 * *$ & $.41 * *$ & $.25^{* *}$ & $.40 * *$ & $.48 * *$ & - & & & \\
\hline 8. POGQ preoccupation & $1-5$ & 2.32 & 0.87 & $.50 * *$ & $.76^{* *}$ & $.51 * *$ & $.33 * *$ & $.37 * *$ & $.59 * *$ & $.41 * *$ & - & & \\
\hline 9. Weekly game time & $1-5$ & 2.46 & 1.12 & $.29 * *$ & $.34 * *$ & $.25^{* *}$ & $.29 * *$ & $.25 * *$ & $.23 * *$ & $.20 * *$ & $.28 * *$ & - & \\
\hline 10. Psychiatric symptoms (BSI) & $0-4$ & 0.47 & 0.52 & $.43 * *$ & $.46^{* *}$ & $.40 * *$ & $.27 * *$ & $.41 * *$ & $.39 * *$ & $.28 * *$ & $.29 * *$ & $.12 *$ & - \\
\hline 11. Impulsivity (BIS-21) & $1-4$ & 1.92 & 0.37 & $.32 * *$ & $.34 * *$ & $.30 * *$ & $.18^{* *}$ & $.28 * *$ & $.24 * *$ & $.36 * *$ & $.18^{* *}$ & $.14 * *$ & $.41 * *$ \\
\hline \multicolumn{14}{|c|}{ Norwegian sample } \\
\hline Scales & Range & M & $\mathrm{SD}$ & 1 & 2 & 3 & 4 & 5 & 6 & 7 & 8 & 9 & 10 \\
\hline 1. IGDT-10 & $0-9$ & .81 & 1.30 & - & & & & & & & & & \\
\hline 2. POGQ total & $1-5$ & 2.12 & 0.65 & $.73 * *$ & - & & & & & & & & \\
\hline 3. POGQ social isolation & $1-5$ & 2.11 & 0.86 & $.61 * *$ & $.80 * *$ & - & & & & & & & \\
\hline 4. POGQ interpersonal conflicts & $1-5$ & 1.99 & 0.96 & $.47 * *$ & $.73^{* *}$ & $.45^{* *}$ & - & & & & & & \\
\hline
\end{tabular}




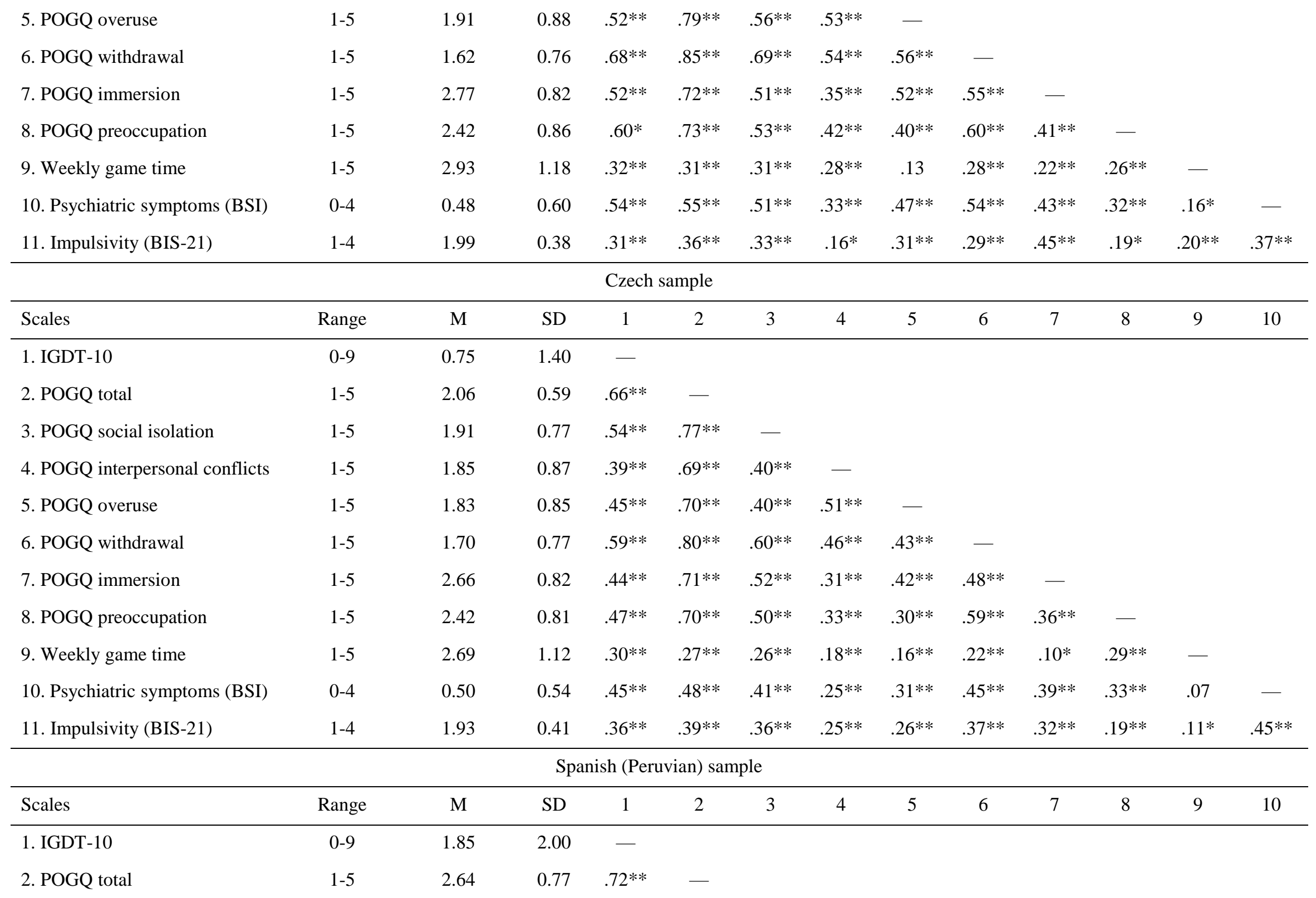




\begin{tabular}{|c|c|c|c|c|c|c|c|c|c|c|c|c|c|}
\hline 3. POGQ social isolation & $1-5$ & 2.42 & 1.01 & $.65^{* *}$ & $.85^{* *}$ & - & & & & & & & \\
\hline 4. POGQ interpersonal conflicts & $1-5$ & 2.51 & 1.07 & $.51 * *$ & $.81 * *$ & $.60 * *$ & - & & & & & & \\
\hline 5. POGQ overuse & $1-5$ & 2.48 & 0.93 & $.52 * *$ & $.79 * *$ & $.65^{* *}$ & $.66^{* *}$ & - & & & & & \\
\hline 6. POGQ withdrawal & $1-5$ & 2.15 & 0.96 & $.62 * *$ & $.85^{* *}$ & $.69 * *$ & $.60 * *$ & $.56^{* *}$ & - & & & & \\
\hline 7. POGQ immersion & $1-5$ & 2.97 & 0.90 & $.59 * *$ & $.82 * *$ & $.65^{* *}$ & $.56^{* *}$ & $.52 * *$ & $.66 * *$ & - & & & \\
\hline 8. POGQ preoccupation & $1-5$ & 3.26 & 0.84 & $.59 * *$ & $.71 * *$ & $.52 * *$ & $.44 * *$ & $.35^{* *}$ & $.57 * *$ & $.59 * *$ & - & & \\
\hline 9. Weekly game time & $1-5$ & 3.26 & 0.99 & $.19 * *$ & $.20 * *$ & $.17 * *$ & $.14^{* *}$ & $.12 * *$ & $.13 * *$ & $.19 * *$ & $.22 * *$ & - & \\
\hline 10. Psychiatric symptoms $(\mathrm{BSI})^{\mathrm{a}}$ & $0-4$ & 0.70 & 0.72 & $.37 * *$ & $.46^{* *}$ & $.42 * *$ & $.37 * *$ & $.42 * *$ & $.43 * *$ & $.40 * *$ & $.23 * *$ & $.11^{* *}$ & - \\
\hline 11. Impulsivity (BIS-21) & $1-4$ & 1.89 & 0.39 & $.31 * *$ & $.48 * *$ & $.43^{* *}$ & $.39 * *$ & $.43 * *$ & $.42 * *$ & $.39 * *$ & $.16^{* *}$ & .02 & $.49 * *$ \\
\hline
\end{tabular}

Note. IGDT-10 = Ten-Item Internet Gaming Disorder Test; POGQ = Problematic Online Gaming Questionnaire; BSI = Brief Symptom Inventory; BIS-21 = Barratt Impulsiveness Scale 21-item version. ${ }^{\text {a }}$ In the case of the Spanish (Peruvian) sample, only the depression and anxiety subscales were assessed and calculations were conducted with the means of these two scales. ** $p<.01 ; * p<.05$ 
Supplemental Table 3. Ten-Item Internet Gaming Disorder Test (IGDT-10) - English version

Please read the statements below regarding online video gaming. The questionnaire refers to ONLINE GAMES, but the reference to 'game' or 'gaming' is used for the sake of simplicity. Please, indicate on the scale from 0 to 2 (Never, Sometimes, Often) to what extent, and how often, these statements applied to you over the PAST 12 MONTHS!

Never Sometimes Often

1. When you were not playing, how often have you fantasized about gaming, thought of previous gaming sessions, and/or $0 \quad 1$ anticipated the next game?

2. How often have you felt restless, irritable, anxious and/or sad when you were unable to play or played less than usual?

$0 \quad 1 \quad 2$

3. Have you ever in the past 12 months felt the need to play more often or played for longer periods to feel that you have played $\begin{array}{lll}0 & 1 & 2\end{array}$ enough?

4. Have you ever in the past 12 months unsuccessfully tried to reduce the time spent on gaming?

$0 \quad 1 \quad 2$

5. Have you ever in the past 12 months played games rather than meet your friends or participate in hobbies and pastimes that you used to enjoy before?

6. Have you played a lot despite negative consequences (for instance losing sleep, not being able to do well in school or work, having arguments with your family or friends, and/or neglecting $0 \quad 1$ important duties)?

7. Have you tried to keep your family, friends or other important people from knowing how much you were gaming or have you $0 \quad 1$ 2 lied to them regarding your gaming?

8. Have you played to relieve a negative mood (for instance helplessness, guilt, or anxiety)?

$0 \quad 1 \quad 2$

9. Have you risked or lost a significant relationship because of gaming?

10. Have you ever in the past 12 months jeopardized your school or work performance because of gaming? 
Administration: The present study targeted online gamers only therefore the instructions were phrased as such. However, in line with the recommendations of the DSM-5, the IGDT-10 can be applied for video games in general. In that case online video gaming should be replaced with video gaming, and ONLINE GAMES should be replaced by 'VIDEO GAMES (both online and offline, played on any platform)' in the instructions.

Scoring: In order to measure the DSM-5 criteria items are recoded into a dichotomous format according to the following: answers "Never" and "Sometimes" are evaluated as the criterion is not met ( 0 point $)$, while "Often" is evaluated as the criterion is met (1 point).

Important: Question 9 and 10 belong to the same criterion, that is, answer "Often" on either Item 9 or Item 10 (or both items) means only 1 point.

Evaluation: DSM-5 considers the case clinically relevant if five or more criteria are met. 
Supplemental Table 4. Ten-Item Internet Gaming Disorder Test (IGDT-10) - Hungarian version

Az alábbiakban az online videojátékok használatával kapcsolatos állításokat olvashatsz. A kérdőív az ONLINE JÁTÉKOKra vonatkozik, de az egyszerüség kedvéért az egyes állításoknál csak a ,játék” kifejezést használjuk. Kérjük, jelezd egy 0-tól 2-ig terjedő skálán (soha, időnként, gyakran), hogy az egyes állítások milyen gyakran fordultak elő veled az ELMÚLT 12 HÓNAPban!

Soha Időnként Gyakran

1. Amikor nem játszottál, milyen gyakran fordult elö, hogy a játékról fantáziáltál; felidézted, hogy milyen volt játszani vagy a $\quad \begin{array}{llll}0 & 1 & 2\end{array}$ legközelebbi játékot tervezted?

2. Milyen gyakran fordult elö, hogy nyugtalannak, lehangoltnak, ingerlékenynek, dühösnek vagy szomorúnak érezted magad, amikor nem volt lehetőséged játszani, vagy kevesebbet játszottál, $\begin{array}{lll}0 & 1 & 2\end{array}$ mint korábban?

3. Tapasztaltad-e, hogy egyre gyakrabban vagy egyre több időt kell játszanod ahhoz, hogy elégnek érezd, amennyit játszottál?

$\begin{array}{lll}0 & 1 & 2\end{array}$

4. Előfordult-e, hogy szeretted volna csökkenteni a játékkal töltött időt, de nem sikerült?

0

12

5. Mennyire fordult elö, hogy kevésbé volt kedved találkozni a barátaiddal vagy csökkent az érdeklődésed olyan programok vagy hobbik iránt, amiket korábban kedveltél, mert inkább játszani volt $0 \quad 1$ 2 kedved?

6. Jellemző-e rád, hogy sokat játszol annak ellenére, hogy tudatában vagy, hogy ez rossz hatással van az életedre (például nem alszol eleget, nem tudsz megfelelően teljesíteni az iskolában vagy a munkahelyeden, vitát okoz a családtagjaiddal, barátaiddal vagy elhanyagolsz a játék miatt egyéb fontos teendőket, stb.)?

7. Előfordult, hogy megpróbáltad eltitkolni családtagjaid, barátaid, vagy más, számodra fontos személy elől, hogy mennyit $\quad \begin{array}{llll}0 & 1\end{array}$ játszol, vagy hazudtál nekik emiatt?

8. Előfordult veled, hogy azért játszottál, hogy kevésbé bántson valamilyen kellemetlen érzés (például szorongás, rossz hangulat, büntudat stb.)?

9. Előfordult, hogy kockára tettél vagy akár el is vesztettél egy fontos kapcsolatot a játszás miatt?

$\begin{array}{lll}0 & 1 & 2\end{array}$

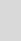


10. Elöfordult, hogy rossz hatással volt a tanulmányi vagy munkahelyi eredményeidre a játék? 
Supplemental Table 5. Ten-Item Internet Gaming Disorder Test (IGDT-10) - Persian (Iranian) version

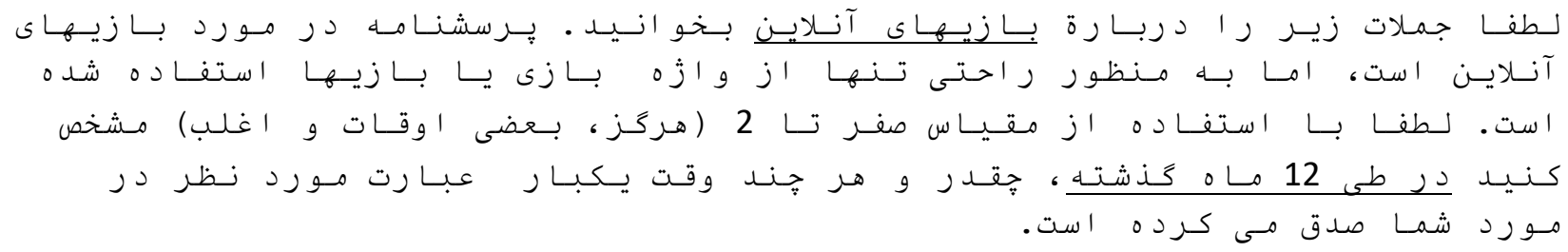

\begin{tabular}{|c|c|c|c|}
\hline ا غلب & 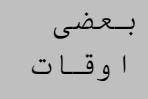 & هـرَــز & \\
\hline 2 & 1 & 0 & 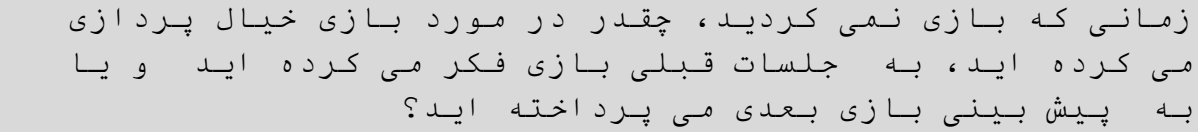 \\
\hline 2 & 1 & 0 & 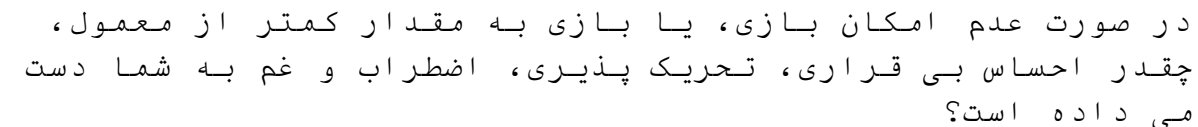 \\
\hline 2 & 1 & 0 & 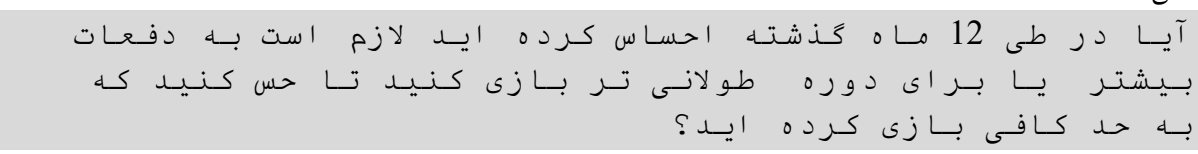 \\
\hline 2 & 1 & 0 & 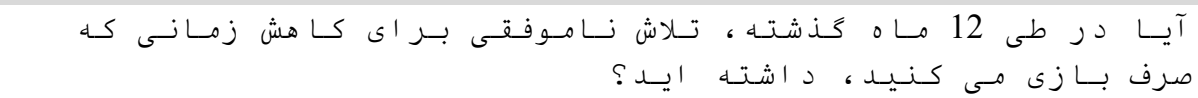 \\
\hline 2 & 1 & 0 & 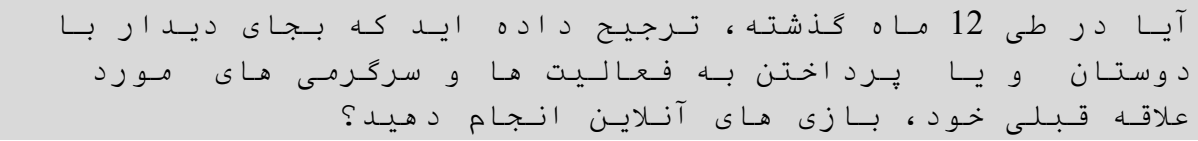 \\
\hline 2 & 1 & 0 & 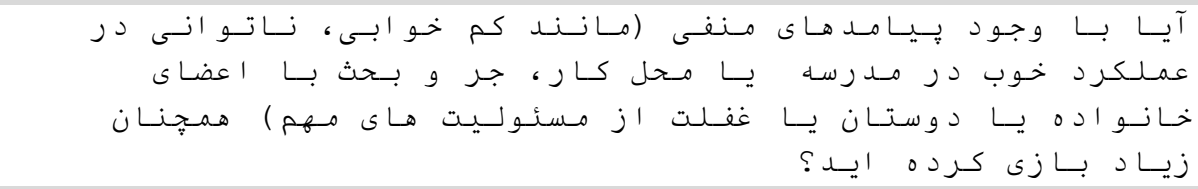 \\
\hline 2 & 1 & 0 & 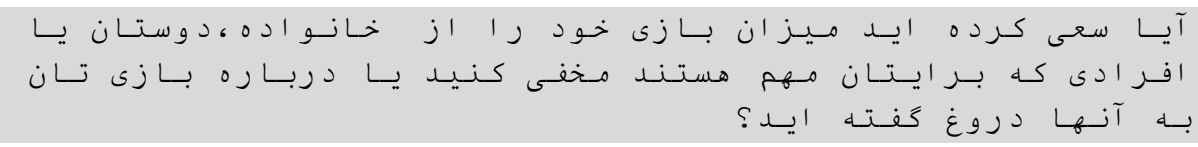 \\
\hline 2 & 1 & 0 & 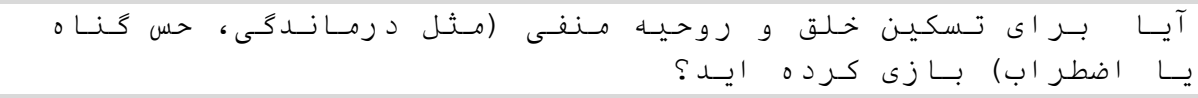 \\
\hline 2 & 1 & 0 & 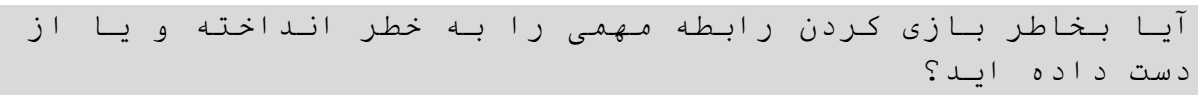 \\
\hline 2 & 1 & 0 & 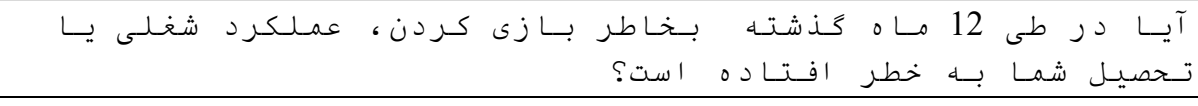 \\
\hline
\end{tabular}


Supplemental Table 6. Ten-Item Internet Gaming Disorder Test (IGDT-10) - French version

Veuillez lire les affirmations suivantes au sujet du jeu vidéo en ligne. Ce questionnaire concerne les JEUX VIDEO EN LIGNE, mais l'utilisation des mots "jeux" et "jouer" sont utilisés pour plus de simplicité. Veuillez indiquer sur une échelle de 0 à 2 (Jamais, Parfois, Souvent) à quel point, et à quelle fréquence, ces affirmations peuvent s'appliquer à vous DURANT LES 12 DERNIERS MOIS!

\section{Jamais Parfois Souvent}

1. Quand vous ne jouez pas, à quelle fréquence vous est-il arrivé de ręvasser au fait de jouer, d'avoir des pensées liées à des 0 2 précédentes sessions de jeu, et/ou d'anticiper la prochaine partie?

2. A quelle fréquence vous ętes-vous senti agité, irritable, anxieux et/ou triste lorsqu'il n'était pas possible pour vous de 0 1 jouer ou lorsque vous jouiez moins que d'habitude?

3. Durant les 12 derniers mois, avez-vous ressenti le besoin de jouer plus souvent, ou sur des durées plus longues, pour avec la sensation d'avoir assez joué?

4. Durant les 12 derniers mois, avez-vous essayé, sans succès, de réduire le temps que vous passiez à jouer?

$\begin{array}{lll}0 & 1 & 2\end{array}$

5. Durant les 12 derniers mois, avez-vous préféré jouer au lieu de voir vos amis ou de participer à des activités et loisirs que vous appréciiez habituellement faire?

6. Avez-vous beaucoup joué malgré la présence de conséquences négatives (ex. réduction des heures de sommeil, inefficacité à l'école ou au travail, disputes avec votre famille ou vos amis, $0 \quad 1 \quad 2$ et/ou négligence d'activités importantes)?

7. Avez-vous essayé de cacher à votre famille, vos amis ou à d'autre personnes importantes pour vous à quel point vous jouez, $\quad \begin{array}{lll}0 & 1\end{array}$ ou menti à propos de vos habitudes de jeu?

8. Avez-vous joué pour soulager une humeur négative (ex. un sentiment d'impuissance, de culpabilité, ou d'anxiété)?

0

9. Avez-vous perdu ou mis en danger une relation avec quelqu'un de proche à cause du jeu? 
10. Durant les 12 derniers mois, avez-vous mis en danger vos résultats scolaires et/ou performances professionnelles à cause du jeu? 
Supplemental Table 7. Ten-Item Internet Gaming Disorder Test (IGDT-10) - Norwegian version

Vennligst les utsagnene under angående online video gaming. Spørreskjemaet refererer til ONLINE VIDEO GAMES, og bruken av 'spill' og 'spille' brukes kun for forenkling. Vennligst indiker på en skala fra 0 til 2 (Aldri, Noen ganger, Ofte) til hvilken grad, og hvor ofte, disse utsagnene gjelder deg over de SISTE 12 MÅNEDENE.

\section{Aldri $\begin{gathered}\text { Noen } \\ \text { ganger }\end{gathered}$ Ofte}

1. Når du ikke spiller, hvor ofte har du fantasert om å spille, tenkt på tidligere ganger du spilte, og/eller gledet deg til neste gang du kan $0 \quad 1$ 2 spille?

2. Hvor ofte har du følt deg rastløs, irritabel, nervøs og/eller lei deg når du har vært uten mulighet til å spille, eller spille mindre enn normalt?

$0 \quad 1 \quad 2$

3. Har du i løpet av de siste 12 månedene følt behov for å spille oftere, eller for lengre tid av gangen, for å føle at du har spilt nok?

$0 \quad 1 \quad 2$

4. Har du i løpet av de siste 12 månedene prøvd å redusere tiden du bruker på å spille uten å klare det?

$\begin{array}{lll}0 & 1 & 2\end{array}$

5. Har du i løpet av de siste 12 månedene spilt spill istedenfor å møte venner eller delta i hobbyer og fritidsaktiviteter som du pleide å like før?

6. Har du spilt mye selv om det har fått negative konsekvenser (for eksempel å miste søvn, ikke klare å gjøre det bra på skole eller jobb, krangle med familie eller venner, og/eller overse viktig plikter)?

7. Har du prøvd å holde familien din, venner, eller andre viktige personer fra å vite hvor mye du spiller, eller har du løyet til dem angående spillingen din?

8. Har du spilt for å avlaste negativt humør (for eksempel hjelpeløshet, skyldfølelse eller angst)?

9. Har du risikert, eller mistet, et betydningsfullt forhold på grunn av spilling?

10. Har du noensinne de siste 12 månedene risikert skole- eller arbeidsytelse på grunn av spilling? 
Supplemental Table 8. Ten-Item Internet Gaming Disorder Test (IGDT-10) - Czech version

Přečtěte si prosím tvrzení níže týkající se onlinového hraní. Dotazník se věnuje ONLINOVÝM HRÁM, ale pro zjednodušení je užíváno termínu „hry“. Označte prosím na škále od 0 do 2 (Nikdy, Někdy, Často), do jaké míry a jak často byla pro vás tato tvrzení platná během MINULÝCH 12 MĚSÍCŮ.

\section{Nikdy Někdy Často}

1. Pokud jste právě nehrál/a, jak často jste snil/a o hraní, přemýšlel nad předchozími herními sezeními a/nebo se těšil/a na další hraní?

$\begin{array}{lll}0 & 1 & 2\end{array}$

2. Jak často jste se cítil/a neklidně, podrážděně, úzkostně a/nebo smutně, když jste si nemohl/a zahrát nebo jste hrál/a méně než $0 \quad 1 \quad 2$ obvykle?

3. Cítil/a jste někdy v posledních 12 měsících potřebu hrát častěji nebo déle, abyste dosáhl/a pocitu, že jste si dost zahrál/a?

4. Zkoušel/a jste někdy v posledních 12 měsících neúspěšně redukovat čas strávený hraním?

$\begin{array}{lll}0 & 1 & 2\end{array}$

5. Upřednostnil/a jste někdy v posledních 12 měsících hraní před setkání s přáteli, koníčky a volnočasovými aktivitami, které jste $\begin{array}{lll}0 & 1 & 2\end{array}$ předtím míval/a rád/a?

6. Hrál/a jste často i navzdory negativním dopadům (např. vynechání spánku, neschopnost podávat dobré výkony v práci nebo škole, $0 \quad 1 \quad 2$ hádky s rodinou/přáteli a/nebo zanedbávání důležitých povinností)?

7. Pokoušel/a jste se zastírat před rodinou/prráteli nebo dalšími důležitými lidmi, jak moc jste hrál/a nebo jim lhal/a o čase stráveném $\begin{array}{lll}0 & 1 & 2\end{array}$ hraním?

8. Hrál/a jste, abyste se zbavil/a negativní nálady (např. bezmocnosti, viny nebo úzkosti)?

$0 \quad 1 \quad 2$

9. Riskoval/a jste nebo ztratil/a důležitý vztah kvůli hraní?

$0 \quad 1 \quad 2$

10. Ohrozil/a jste během posledních 12 měsíců kvůli hraní své školní nebo pracovní výsledky? 
Supplemental Table 9. Ten-Item Internet Gaming Disorder Test (IGDT-10) - Spanish (Peruvian) version

Por favor, lea los enunciados respecto a los juegos online. El cuestionario hace referencia a SOLO JUEGOS ONLINE. En una escala del 0 al 2 indica en qué medida y frecuencia estas preguntas lo caracterizan en los ULTIMOS 12 MESES. *Recuerda, "gaming” hace referencia la acción de jugar videojuegos.

$\begin{array}{ccc}\text { Nunca } & \text { A } & \text { A } \\ \text { veces } & \text { menudo }\end{array}$

1. Cuando no se encuentra jugando, ¿con qué frecuencia ha fantaseado con el gaming, pensado en sesiones de juegos $0 \quad 1 \quad 2$ anteriores, y / o anticipado el próximo partido?

2. ¿Con qué frecuencia se ha sentido inquieto, irritable, ansioso y/o triste cuando no pudo jugar o jugó menos de lo habitual?

$0 \quad 1 \quad 2$

3. En los últimos 12 meses, ¿alguna vez ha sentido la necesidad de jugar más seguido o jugó por periodos más largos para sentir que había jugado lo suficiente?

4. En los últimos 12 meses, ¿alguna vez ha intentado disminuir el tiempo que le dedica al gaming pero no lo ha logrado?

$0 \quad 1 \quad 2$

5. En los últimos 12 meses, ¿alguna vez ha preferido el gaming en lugar de estar con sus amigos o participar en pasatiempos que antes solía disfrutar?

6. ¿Ha jugado durante mucho tiempo a pesar de las consecuencias negativas (por ejemplo, pérdida de sueño, tener un mal rendimiento en los estudios, discutir con tu familia o amigos, y/o $0 \quad 1 \quad 2$ descuidar algunos deberes importantes?

7. ¿Ha tratado de evitar que su familia, amigos u otras personas importantes sepan cuánto tiempo le dedica al gaming o les ha $\begin{array}{ll}0 & 1\end{array}$ 2 mentido acerca de esto?

8. ¿Ha jugado para aliviar un estado de ánimo negativo (por ejemplo, impotencia, culpa, ansiedad)?

$0 \quad 1 \quad 2$

9. ¿Ha arriesgado o perdido una relación importante debido al gaming?

10. En los últimos 12 meses, ¿alguna vez ha puesto en riesgo su rendimiento académico por el gaming? 
